OPEN ACCESS

Edited by: Samuel Abiven, Universität Zürich, Switzerland

Reviewed by:

Stefan Doerr

Swansea University, United Kingdom

Laure Nalini Soucemarianadin,

École Normale Supérieure, France

*Correspondence:

Rebecca B. Abney rebabney@iu.edu

Specialty section:

This article was submitted to

Biogeoscience

a section of the journal

Frontiers in Earth Science

Received: 30 November 2017

Accepted: 05 March 2018

Published: 20 March 2018

Citation:

Abney RB and Berhe AA (2018)

Pyrogenic Carbon Erosion:

Implications for Stock and Persistence

of Pyrogenic Carbon in Soil.

Front. Earth Sci. 6:26

doi: 10.3389/feart.2018.00026

\section{Pyrogenic Carbon Erosion: Implications for Stock and Persistence of Pyrogenic Carbon in Soil}

\author{
Rebecca B. Abney ${ }^{1,2 \star}$ and Asmeret Asefaw Berhe ${ }^{1}$ \\ 1 Environmental Systems, Life and Environmental Sciences, University of California, Merced, Merced, CA, United States, \\ ${ }^{2}$ School of Public and Environmental Affairs, Indiana University, Bloomington, IN, United States
}

Pyrogenic carbon (PyC) constitutes an important pool of soil organic matter (SOM), particularly for its reactivity and because of its assumed long residence times in soil. In the past, research on the dynamics of PyC in the soil system has focused on quantifying stock and mean residence time (MRT) of PyC in soil, as well as determining both PyC stabilization mechanisms and loss pathways. Much of this research has focused on decomposition as the most important loss pathway for PyC from soil. However, the low density of PyC and its high concentration on the soil surface after fire indicates that a significant proportion of PyC formed or deposited on the soil surface is likely laterally transported away from the site of production by wind and water erosion. Here, we present a synthesis of available data and literature to compare the magnitude of the water-driven erosional PyC flux with other important loss pathways, including leaching and decomposition, of PyC from soil. Furthermore, we use a simple first-order kinetic model of soil PyC dynamics to assess the effect of erosion and deposition on residence time of PyC in eroding landscapes. Current reports of PyC MRT range from 250 to 660 years. Using a specific example-based model system, we find that ignoring the role of erosion may lead to the under- or over-estimation of PyC MRT on the centennial time scale. Furthermore, we find that, depending on the specific landform positions, timescales considered, and initial concentrations of $\mathrm{PyC}$ in soil, ignoring the role of erosion in distributing PyC across a landscape can lead to discrepancies in PyC concentrations

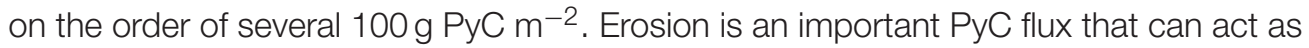
a significant control on the stock and residence time of PyC in the soil system.

Keywords: soil carbon stabilization, erosion, fire, persistence, pyrogenic carbon

\section{INTRODUCTION}

\section{Fires and Production of Pyrogenic Carbon}

Fire is a major environmental perturbation and driver of biogeochemical processes across a diversity of landscapes worldwide. Globally, over 400 million hectares are burned annually (Andela et al., 2017), and in the US alone, wildfires consume over 2.6 million hectares per year in over 74,000 wildfires (National Interagency Fire Center, 2015). The amount and properties of organic matter 
(OM) left behind in and on soil post-fire are controlled by the amount and composition of fuel and the duration and temperature of the fire (Dyrness and Norum, 1983; Kasischke et al., 2008). Depending on burn severity, or the impact of the fire on the ecosystem, fires also control nutrient availability, water infiltration, soil pH (Certini, 2005), and OM stocks in soil (González-Pérez et al., 2004; Keeley, 2009). Moreover, fires can lead to the formation of pyrogenic carbon $(\mathrm{PyC})$ from the incomplete combustion of biomass and soil organic matter (SOM) (Schmidt and Noack, 2000; Masiello, 2004; Preston and Schmidt, 2006). Pyrogenic carbon is a broad term for fire-altered materials that includes a continuum of materials such as soot, charcoal, lightly charred biomass, and biochar, or intentionally charred material for agricultural and carbon (C) sequestration purposes (Masiello, 2004; Bird et al., 2015; Lehmann and Joseph, 2015).

A growing body of literature now demonstrates that $\mathrm{PyC}$ is a major component of the global C cycle (Lehmann et al., 2008; Preston, 2009; Bird et al., 2015). PyC makes up 2.5-5\% of global soil organic C (IPCC, 2013; Bird et al., 2015) and up to $30 \%$ of C in some soils (Skjemstad, 1996; Skjemstad et al., 1999), making it important not just for accounting of global soil C stocks but also for how the soil system plays an important role in regulation of global climate (Lehmann et al., 2008). In soil, PyC has an overall longer mean residence time (MRT, centuries to millennia) (Hammes et al., 2008; Lehmann et al., 2008), compared with non-pyrogenically altered OM (decades to centuries) (Torn et al., 1997; Schmidt et al., 2011). Current estimates of the MRT of $\mathrm{PyC}$ in the soil are considerably shorter than previously reported estimates (on the order of millennia), as several studies have demonstrated that some PyC is degraded on shorter (months to years) time scales in both laboratory (Nguyen et al., 2009; Whitman et al., 2014) and field studies (Soucémarianadin et al., 2015). Recent observations have indicated that current estimates of $\mathrm{PyC}$ residence times may be inaccurate due to failures in accurately quantifying lateral redistribution of $\mathrm{PyC}$ in the terrestrial ecosystem and its riverine transfer to the ocean (Rumpel et al., 2006; Jaffé et al., 2013; Masiello and Louchouarn, 2013).

\section{Effect of Fire and PyC on Soil Erosion}

Elevated rates of post-fire soil erosion are typically observed after wildfires (Certini, 2005; Carroll et al., 2007; Shakesby, 2011). The extent to which fires lead to soil erosion and the nature of the eroded material vary depending on fire type (i.e., crown fire, ground fire), the environment where the fires occur, and post-fire climatic conditions (Certini, 2005; Shakesby, 2011). One of the main controls on the type of fire is the ecosystem type (Kozlowski and Ahlgren, 1974; Brown and Smith, 2000), which dictates the type and quantity of vegetation available for charring into $\mathrm{PyC}$ along with climatic variables responsible for controlling vegetation growth and fire conditions. During fires, typically only the top few (2-5) centimeters of soil are directly and significantly impacted by the high temperatures (DeBano, 2000). Charring intensity, or the integral of the duration and maximum temperature reached during combustion of organic matter (Pyle et al., 2015), at the soil surface controls the properties of the $\mathrm{PyC}$ formed during the fire, where $\mathrm{PyC}$ formed at higher temperatures (above $\sim 350^{\circ} \mathrm{C}$ ) can be more persistent in soil (González-Pérez et al., 2004; Zimmerman, 2010). Generally, this PyC formed at higher temperatures (above $\sim 350^{\circ} \mathrm{C}$ ) has a higher skeletal density and is more porous (Brewer et al., 2014), making it more susceptible to erosional transport than low temperature PyC.

Fire also changes the physical properties of soil with implications for lateral movement of water and PyC. Fires can lead to destabilization of topsoil, reducing aggregation and aggregate protected $\mathrm{C}$, increased soil hydrophobicity, which can lead to increased erodibility of soil post-fires through both water and wind-driven erosion processes (Shakesby and Doerr, 2006; Johnson et al., 2007; Ravi et al., 2007; Al-Hamdan et al., 2012; Miller et al., 2012; Araya et al., 2017). Albalasmeh et al. (2013), for example, showed that low severity fires can have a lasting impact on soil aggregate stability. Moreover, low to moderate temperature, ground-level fires (soil temperatures reaching $\sim 175-250^{\circ} \mathrm{C}$ ) can lead to the formation of a hydrophobic layer at or just below the soil surface, or increases in any pre-existing soil hydrophobicity, resulting in decreases in infiltration rates (DeBano, 2000; Shakesby and Doerr, 2006; Mataix-Solera et al., 2011). This decrease in infiltration and altered hydrologic flow paths though the soil matrix can lead to increases in overland flow (Hortonian flow, see Figure 1, Shakesby and Doerr, 2006). In combination with the loss of soil-stabilizing vegetation during fire, this increase in overland flow can drive increased erosion rates and sediment export in fire-affected landscapes (Shakesby et al., 1993).

\section{EROSION AND PyC PERSISTENCE IN SOIL}

Over the last couple of decades, our understanding of how PyC becomes stabilized in, or is lost from, the soil system has advanced considerably. However, many of these calculations and measurements of PyC stabilization have not considered erosion. In the following sections, we discuss historical and modern ideas about $\mathrm{PyC}$ persistence within soil and the role of erosion as a loss and stabilization mechanism.

\section{Historical Perspective}

Historically, PyC was thought to be a highly recalcitrant form of soil C that is inherently resistant to microbial decomposition. The presumed chemical recalcitrance of $\mathrm{PyC}$ was attributed to its chemical structure including large linkages of condensed aromatic structures (Skjemstad et al., 1999), as well as it forming chemical and physical associations with soil minerals (Lehmann et al., 2005; Brodowski et al., 2006). This idea of chemical recalcitrance prevailed for decades, even though there was evidence for the breakdown of $\mathrm{PyC}$ from the beginning of the twentieth century (Potter, 1908). This presumed inherent recalcitrance of $\mathrm{PyC}$ was even used to support arguments that PyC storage in soil might be part of the "missing C sink" because it seemed so environmentally stable (Lehmann, 2007). At the same time, the ability of $\mathrm{PyC}$ to persist in the soil longer than non- $\mathrm{PyC} \mathrm{OM}$, has also contributed to the widespread research 


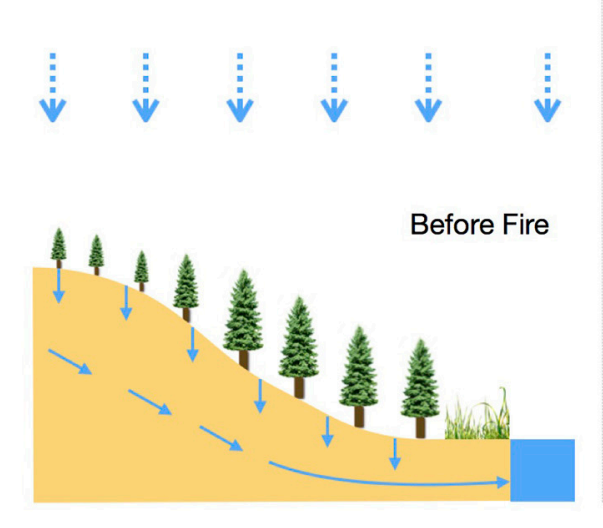

\section{औ.

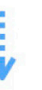

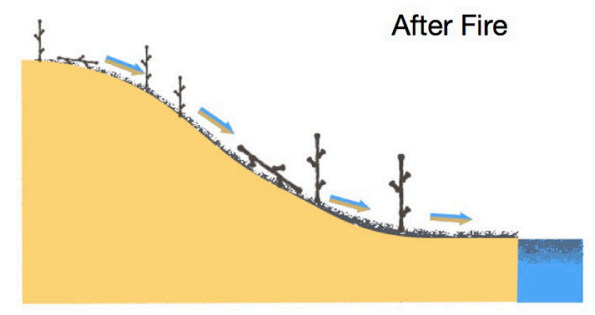

FIGURE 1 | On the hillslope scale, fires alter dominant hydrologic flow regimes in soil, reducing infiltration and subsurface flow of water, and increasing surface runoff.

on the potential of PyC to serve as an agricultural amendment (biochar) with the main aim of increasing soil $\mathrm{C}$ stocks and decreasing $\mathrm{C}$ turnover (i.e., improving a soil's potential to sequester atmospheric $\mathrm{CO}_{2}$; Lehmann et al., 2008); however some other types of biochar can be utilized to improve soil productivity (Lehmann and Joseph, 2015). However, recent works showed $\mathrm{PyC}$ can become decomposed or lost from soil rather quickly, on the scale of months to years (Nguyen et al., 2010; Zimmerman, 2010; Zimmermann et al., 2012; Zimmerman and Gao, 2013).

There is now a major paradigm shift occurring in our understanding of PyC dynamics in the earth system. Figure 2 shows how published estimates of PyC MRT have decreased over the last few decades. Some earlier studies reported MRT estimates over thousands of years, but around 2008, a gradual shift in viewpoints happened as evidence for rapid decomposition and mobilization became apparent (Figure 2). Some of the most recent research suggests that the rate of $\mathrm{PyC}$ decomposition is tightly controlled by environmental conditions and its persistence in soil is a property of the ecosystem (Schmidt et al., 2011).

\section{Stability and Turnover of PyC}

PyC can become stabilized or lost from soil through similar processes that control the fate of bulk or non-pyrogenic carbon, including biotic and abiotic decomposition, leaching, and erosion (Rumpel et al., 2006; Major et al., 2010; Zimmerman, 2010). Current estimates of PyC MRT range from weeks to months to millennia (Bird et al., 2015). Lehmann et al. (2008) suggested that PyC MRT in soil could range between 700 and 9,000 years. However, other studies have argued that PyC has considerably shorter MRT in soil (Table 1). For example, Hammes et al. (2008) found a PyC turnover time of 239 years in a Russian steppe site, and similarly, Boot et al. (2015) found a similar MRT for PyC of 300 years. Overall, laboratory incubation derived estimates of loss of $\mathrm{PyC}$ are typically higher (1.5-20\% PyC mass loss per year) than field studies (0.08-15\% PyC mass loss per year), even though field studies include other forms of loss other than microbial decomposition (e.g., erosion and leaching, Table 1). Much of the variation in field and laboratory studies is due to the range of different processes that control PyC persistence in soil, and laboratory studies are commonly conducted under ideal decomposition conditions, which are more reflective of near maximum potential breakdown rates of PyC. Below, we present a discussion on the role of erosion in controlling the dynamics of $\mathrm{PyC}$ in the soil system.

\section{Erosion as a Driver of C Dynamics in Soil}

Interest in the role of erosion on soil $\mathrm{C}$ and $\mathrm{PyC}$ dynamics and biogeochemical cycling of essential elements has increased over the last two decades. In particular, research has focused on the potential for erosion to constitute a net sink for atmospheric $\mathrm{CO}_{2}$, on the order of $0.12-1.5 \mathrm{Gt} \mathrm{C} \mathrm{y}^{-1}$ (Stallard, 1998; Lal, 2003; Berhe et al., 2007; Battin et al., 2009; Regnier et al., 2013; Doetterl et al., 2016). In upland, eroding landform positions (shoulder positions), erosion leads to losses of SOM through direct removal of soil mass (Berhe et al., 2008; Harden et al., 2008; Berhe, 2012; Nadeu et al., 2012; Stacy et al., 2015; McCorkle et al., 2016). About $70-90 \%$ of the eroded topsoil material is redistributed downhill or downstream, and this material is not exported out of the source watersheds but instead is deposited in toeslope and footslope landform positions (Gregorich et al., 1998; Stallard, 1998; Lal, 2003). Erosion leads to stabilization of at least some of the eroded SOM in depositional landforms through new and reconfigured associations of the eroded SOM with soil minerals (Sharpley, 1985; Lal, 2003, 2004; Berhe, 2012; Berhe and Kleber, 2013). During the transport phase of erosion, eroded material is exposed to breakdown mechanisms and for non-pyrogenic C, over $20 \%$ of the OM transported from eroding landform positions is assumed to be lost via oxidative decomposition during or after transport (Jacinthe and Lal, 2001). Erosion is a particularly important flux for PyC in soil when it stays on surface layers (Rumpel et al., 2006) at least on the order of months, if not longer (Boot et al., 2015; Faria et al., 2015), because this leaves PyC vulnerable to weathering forces of wind and water. However, current research has focused on hillslope- and plot-scale erosion of PyC (Rumpel et al., 2006, 2009; Abney et al., 2017; Pyle et al., 2017), so its redistribution at the watershed and larger scales remains largely unknown. 


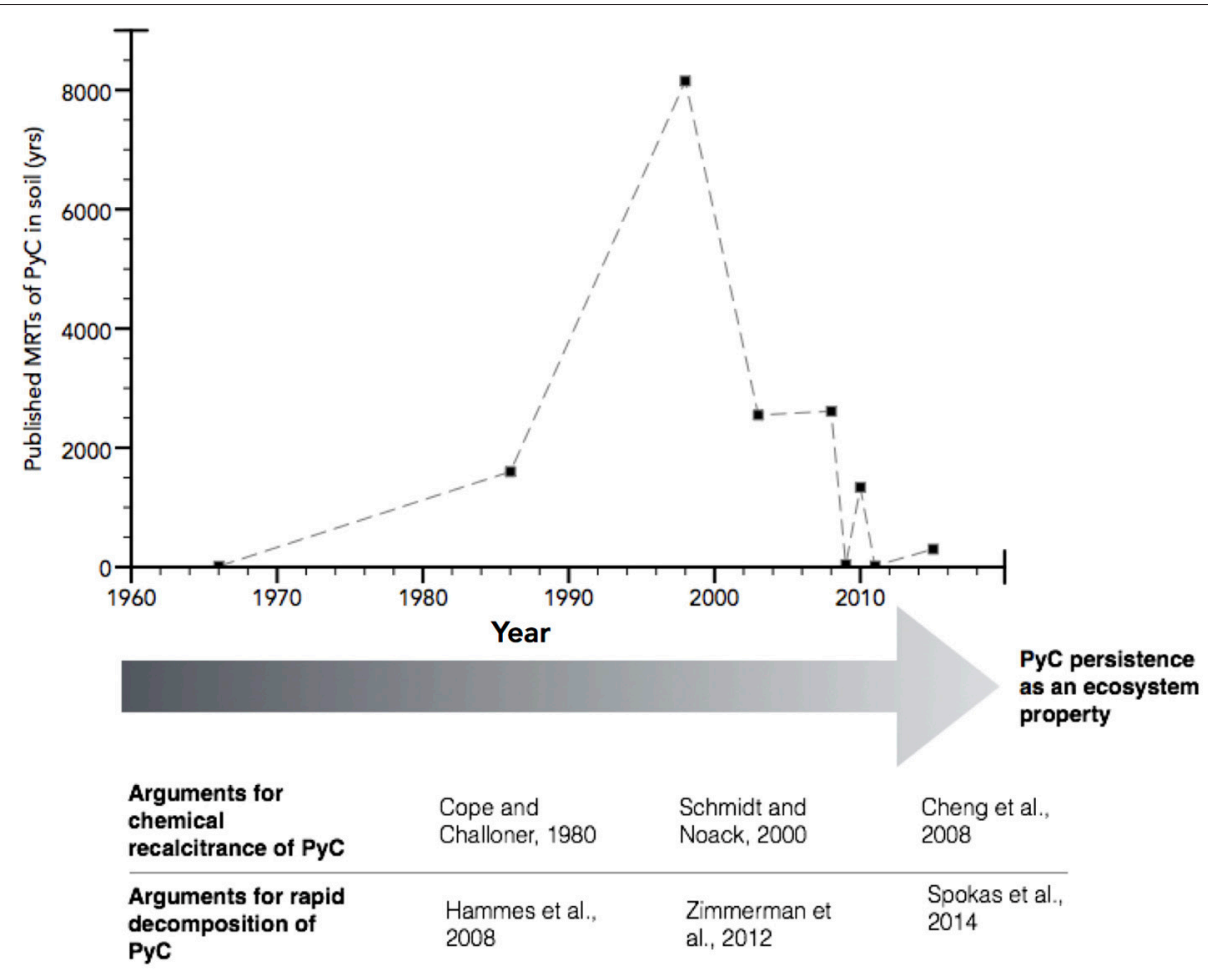

FIGURE 2 | This timeline of estimated MRTs of PyC and key papers illustrates the changing paradigm on controls of PyC persistence in the soil system. The estimate for char age from Cope and Chaloner (1980) was not included in the average of 300 million years, because it was not an estimate of turnover time, but it does reflect the view that $\mathrm{PyC}$ would reside in soil for very extended periods of time. Also, note that the $\mathrm{x}$-axis is not numeric.

\section{Post-fire Erosion}

Fire increases the susceptibility of soils, particularly surface soils, to erosion by changing soil physical and chemical properties (Certini, 2005). For example, the development of soil hydrophobicity post-fire can reduce water infiltration, increasing topsoil susceptibility to runoff (DeBano, 2000). The presence of $\mathrm{PyC}$ in litter and surface soil can also increase the rates of bulk erosion, as fire-affected biomass tends to have lower density, compared to uncharred biomass and litter, making it easier to transport by both water- (Rumpel et al., 2006) and winddriven (Beyers et al., 2005; Shakesby, 2011) erosional processes. In many ecosystems, erosion preferentially transports carbonaceous topsoil material, compared to mineral constituents of soil, leading to $\mathrm{C}$ enrichment in eroded sediments compared to soil in source slopes (Avnimelech and McHenry, 1984; Stacy et al., 2015).

Similarly, Rumpel et al. (2006) found evidence for selective transport of $\mathrm{PyC}$ during interrill erosion due to its lower density and concentration on the soil surface. One study found that interrill sediment erosion was doubled in a burned watershed compared to a neighboring unburned watershed, along with increases in runoff velocity due to increased bare ground coverage (Pierson et al., 2008, 2013). The relative extent of interrill compared with rill erosion depends upon local landscape and precipitation conditions, where higher precipitation intensity and steeper slopes can drive increased rill formation (Moody et al., 2013). The relative role of rill and interrill erosion can control the mobility of $\mathrm{PyC}$ throughout a landscape, as rill erosion likely would not preferentially transport $\mathrm{PyC}$ and would result in transport of bulk soil material (Schiettecatte et al., 2008), while sheet or interrill erosion can preferentially transport smaller, lighter, and organic-rich material (Wang et al., 2010).

\section{Atmospheric and Aeolian Transport of PyC}

The atmospheric component of the global PyC cycle has received considerably more research focus than soil PyC, largely due to the interest in air pollution associated with soot and other aerosols released to the atmosphere during fires (Seiler, 1980; Campbell et al., 2007), and their implications for global climate change and public health (Highwood and Kinnersley, 2006; Bond et al., 2013). Fossil fuel combustion and biomass burning produce the majority of atmospheric PyC, which has a relatively short residence time (up to months) in the atmosphere (Chapin et al., 2006; Preston and Schmidt, 2006), and an even shorter (<week) in the lower atmosphere (Parungo et al., 1994).

Dry and wet deposition of $\mathrm{PyC}$ from the atmosphere is a global process that transports 2-10 $\mathrm{Tg} \mathrm{PyC}$ per year, to both land and ocean depositional settings spanning thousands of $\mathrm{km}$ (Parungo et al., 1994; Jurado et al., 2008; Bond et al., 2013). From the soil surface, soot and smaller PyC constituents can be rapidly transported post-fire (Figure 3), depending on local wind and precipitation conditions, such that dry climates are 
TABLE 1 | Examples of decomposition rates measured in laboratory and field studies, as converted to percent mass loss of PyC per year.

\begin{tabular}{|c|c|c|c|c|}
\hline $\begin{array}{l}\% \mathrm{PyC} \text { mass } \\
\text { loss in a year }\end{array}$ & Type of experiment & Source of PyC & Method to measure PyC & Citation \\
\hline \multicolumn{5}{|c|}{ LABORATORY EXPERIMENTS } \\
\hline $10-20$ & $\begin{array}{l}\text { Incubation, temperature change from } \\
4 \text { to } 60^{\circ} \mathrm{C}\end{array}$ & $\begin{array}{l}\text { Laboratory generated corn (Zea mays } \\
\text { L.) char at } 350^{\circ} \mathrm{C}\end{array}$ & $\begin{array}{l}{ }^{13} \mathrm{C} \text { direct polarization NMR } \\
\text { spectroscopy }\end{array}$ & Nguyen et al., 2010 \\
\hline $2.3-15$ & & Oak (Quercus spp.) char at $350^{\circ} \mathrm{C}$ & & \\
\hline $1.5-14$ & & Oak char at $600^{\circ} \mathrm{C}$ & & \\
\hline $0.02-4.89$ & $\begin{array}{l}\text { Three simulations of PyC loss via } \\
\text { decomposition ranging from } 2 \text { to } \\
2,000 \text { years }\end{array}$ & $\mathrm{N} / \mathrm{A}$ & $\mathrm{N} / \mathrm{A}$ & Foereid et al., 2011 \\
\hline 0.38 & Laboratory incubation-O horizon & $\begin{array}{l}\text { Laboratory generated char from } \\
\text { ponderosa pine (Pinus ponderosa) }\end{array}$ & Chemo-thermal oxidation at $375^{\circ} \mathrm{C}$ & $\begin{array}{l}\text { Hatten and Zabowski, } \\
2009\end{array}$ \\
\hline 0.25 & $\begin{array}{l}\text { Average PyC loss between years } 5 \\
\text { and } 8\end{array}$ & & & \\
\hline \multicolumn{5}{|c|}{ FIELD EXPERIMENTS } \\
\hline 1 & $\begin{array}{l}\text { Field chronosequence: first } 30 \text { years } \\
\text { after production }\end{array}$ & Field burning of maize (Zea mays L.) & $\begin{array}{l}{ }^{13} \mathrm{C} \text { CPMAS NMR spectroscopy, } \\
\text { FTIR }\end{array}$ & $\begin{array}{l}\text { Nguyen and Lehmann, } \\
2009\end{array}$ \\
\hline 3.2 & $\begin{array}{l}\text { Field chronosequence: first } 5 \text { years } \\
\text { after production }\end{array}$ & & Manual identification & \\
\hline 1.1 & Field experiment in native savannah & Mango trees (Mangifera indica L.) & $\begin{array}{l}\text { Mixing model from } \delta^{13} \mathrm{C} \text { of } \mathrm{PyC} \text { and } \\
\text { field soil }\end{array}$ & Major et al., 2010 \\
\hline 0.25 & Field experiment & Natural PyC in chernozem & BPCA & Hammes et al., 2008 \\
\hline
\end{tabular}

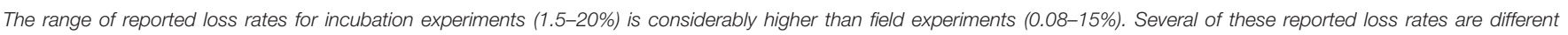

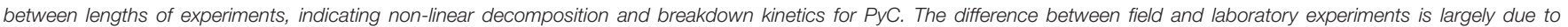

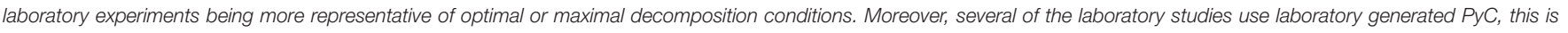
critical to control and account for the variation in PyC found in the field and in the case of wildfires.

more susceptible to post-fire wind erosion (Shakesby, 2011; Pereira et al., 2015). Few studies have focused on winddriven erosion, atmospheric transport, and terrestrial deposition of PyC post-fire, due to both methodological difficulties and widespread assumptions that it is a very small flux or only a site-specific phenomenon (Wondzell and King, 2003; Shakesby, 2011). However, it is likely that smaller, low-density PyC, or PyC produced by higher temperature fires (Brewer et al., 2014), could be rapidly transported significant distances, particularly with the loss of vegetation and breakdown of soil structure post-fire (Beyers et al., 2005).

\section{Stabilization of Eroded PyC via Burial}

The stabilization of PyC can occur through post-erosion burial of a fraction of the eroded $\mathrm{PyC}$ in depositional landform positions, similar to non-pyrogenic C (Berhe et al., 2007; Berhe and Kleber, 2013; Doetterl et al., 2016). PyC-rich material eroded from hillslopes can get stabilized in deep soil layers of downhill or downstream depositional landform positions with repeated erosion/deposition events, especially if it is buried at $>1 \mathrm{~m}$ depths, as was observed in char-rich Paleosols in Nebraska
(Chaopricha and Marín-Spiotta, 2014; Marín-Spiotta et al., 2014). This deep-soil stabilization can also be driven by aeolian-derived deposits burying an existing soil (Chaopricha and Marín-Spiotta, 2014; Marín-Spiotta et al., 2014), via anthropogenic burial, such as the Terra Preta soils of the Amazon (Glaser et al., 2000; Glaser, 2002), or via charring of roots at depth during high intensity fires (Kyuma et al., 1985). The burial of PyC reduces PyC exposure to microbes, air, and extracellular enzymes, which are major drivers of decomposition.

\section{SIGNIFICANCE OF EROSIONAL REDISTRIBUTION OF PYC IN THE TERRESTRIAL ECOSYSTEM}

As of yet, the relative rates of PyC erosion, compared with bulk SOM erosion at the plot, hillslope, or even watershed scale remain relatively unexplored, so the amount of PyC transported via erosion processes is largely unknown. Accurate quantification of the rates of $\mathrm{PyC}$ loss through biological (decomposition) versus physical (erosion, leaching) processes is necessary for fully understanding its role in the soil $\mathrm{C}$ pool, including its potential 

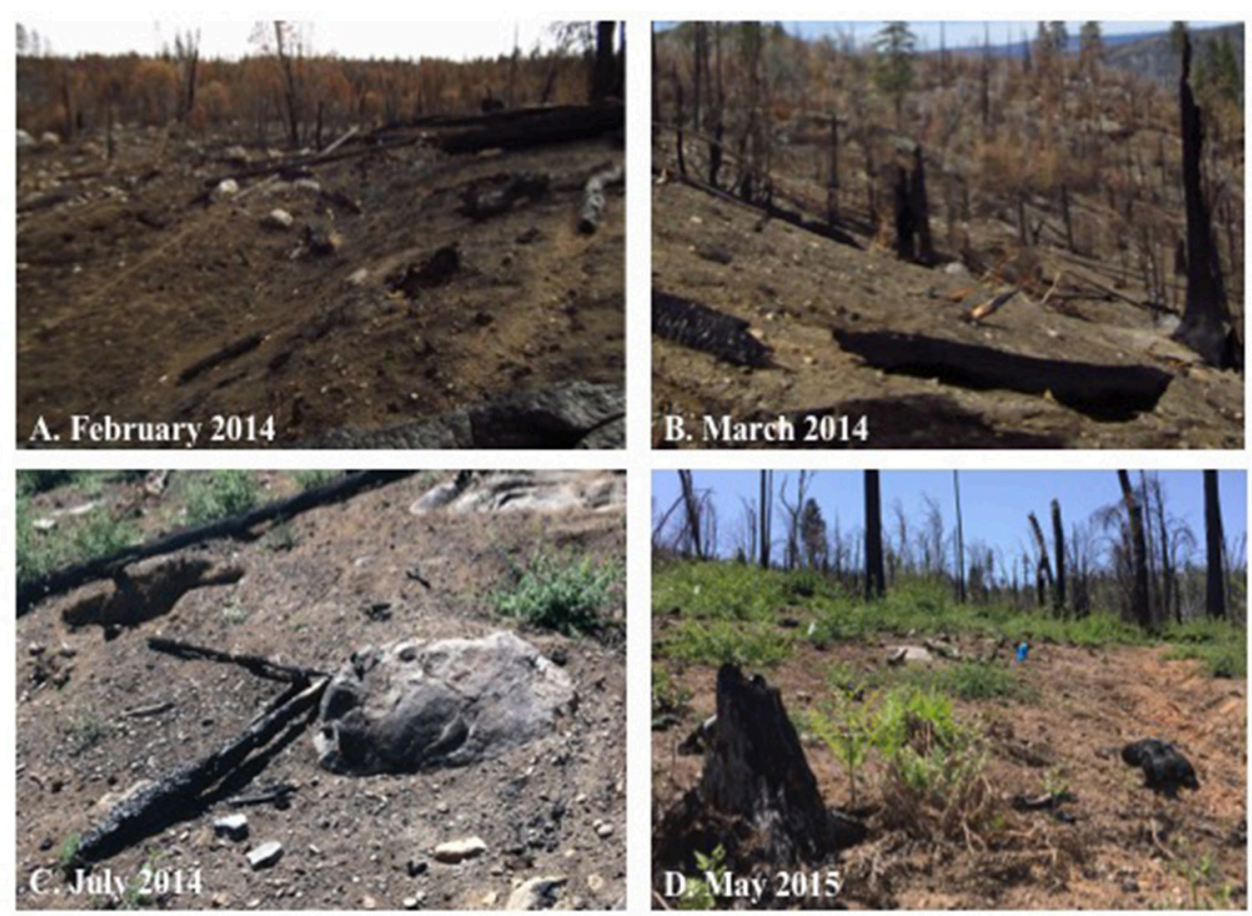

FIGURE 3 | Erosion in upland temperate forests is dependent upon precipitation and topography. This progression of photographs from the Rim Fire (2013, in Yosemite National Park and Stanislaus National Forest in California, USA) illustrates the significant loss of PyC post-fire in a high-severity burn area and post-fire vegetation regrowth (all photos, R. Abney). The Rim Fire began in August of 2013 and was contained in November of 2013, with the aid of snowfall. The picture in (A) (from February 2014, 3 month's post-fire) illustrates the significant PyC layer remaining after the first snowmelt. The picture in (B) from March 2014 is the remaining PyC after the first major rainfall post-fire. The soil color is considerably lighter (3-5/1 5YR dark gray compared with $2.5 / 15 Y R$ black), which is evidence of loss (erosion) of highly charred material (PyC). The pictures in (C,D) have considerably less PyC covering the soil surface and illustrate the beginnings of vegetation regrowth based on ocular assessment after the Rim Fire.

role as a C sink (Hammes et al., 2008). Due to recent research indicating that PyC is preferentially eroded (Rumpel et al., 2006, 2009), it is likely that it will be redistributed throughout the landscape differently than non-pyrogenic carbon, and this may have significant impacts on our understanding of its long-term persistence in soil, as is true for non-pyrogenic carbon (Berhe, 2012; Berhe et al., 2012).

Recent evidence suggests that PyC often interacts with the soil minerals and microbial community differently than some forms of non-pyrogenic C (Kuzyakov et al., 2009; Zimmerman, 2010; Zimmerman et al., 2011), which makes measuring the fluxes of PyC critical for quantifying global PyC stocks. Furthermore, understanding of the controls on the fluxes of PyC through soil is needed for generating more accurate and representative models of dynamics of the soil $\mathrm{C}$ pool and how the soil system controls global climate. Thus, improved understanding of $\mathrm{PyC}$ interactions in soil and its loss mechanisms are currently needed to elucidate the role of $\mathrm{PyC}$ in soil total $\mathrm{C}$ dynamics.

\section{Erosion and Soil PyC Dynamics}

The role of erosion in controlling the fate of $\mathrm{PyC}$ is likely more important than for non-pyrogenic SOM, as fire can significantly increase the rate of soil erosion, and prior research has demonstrated that PyC is highly erodible (Rumpel et al., 2006; Yao et al., 2014). The increased rate of soil erosion post-fire results from a combination of environmental changes, including: loss of the protective litter layer, exposure of surface soil to erosive forces (precipitation, wind), increased hydrophobicity of the subsoil (DeBano et al., 1998; DeBano, 2000; BenavidesSolorio and MacDonald, 2001; MacDonald et al., 2001), and a reduction in water infiltration and water holding capacity of the surface soil (Robichaud, 1997; DeBano, 2000; Doerr and Thomas, 2000; Carroll et al., 2007). Furthermore, the time that elevated rates of soil erosion are sustained is at least partially controlled by the extent of vegetation recovery post-fire, but is typically around a year (Baker, 1988).

Erosion, in turn, can indirectly affect vegetation and soil water status. Both fire and erosion are controlled by climate to various extents (Imeson and Lavee, 1998; Neary et al., 1999; Riebe et al., 2001). Watershed size and topography (Liu et al., 2003; Iniguez et al., 2008), in addition to the amount, intensity, and temporal distribution of precipitation can influence the rate of bulk SOM and $\mathrm{PyC}$ loss from or redistribution within an eroding watershed (Nearing, 1998; Cain et al., 1999; Rumpel et al., 2009). These relationships have been documented by many erosion prediction models, such as the Universal Soil Loss Equation (Wischmeier and Smith, 1965, 1978) and the Water Erosion Prediction Project 
(WEPP) model, which were originally developed in agricultural soils (Laflen et al., 1991).

Important inferences can be drawn on factors that control PyC erosion based on available data and by extrapolation of what we know about erosion of non-PyC or bulk C. Below we briefly discuss how specific variables (i.e., the amount and nature of $\mathrm{PyC}$ available for transport, climate, geomorphology of the landscape) control how strongly erosion can regulate soil PyC dynamics.

\section{The Erodible Nature of PyC}

The amount and composition of $\mathrm{PyC}$ that is laterally distributed over the soil surface by erosion, at least in part, depends on the concentration, location, chemical composition, and physical size of the PyC. These variables are all products of complex interactions among the type and density of vegetation available to be combusted (i.e., fuel load), combustion conditions (e.g., temperature, duration, oxygen availability), and frequency of fire events (Schmidt and Noack, 2000; Masiello, 2004; Hockaday et al., 2006; Czimczik and Masiello, 2007; Knicker, 2007).

Transport of $\mathrm{PyC}$ is assumed to occur in erosion events immediately after fire when the land surface is covered by a layer of $\mathrm{PyC}$, which can become quickly mobilized through the landscape via either wind- or water-driven erosion processes (Carroll et al., 2007; Pereira et al., 2015; Abney et al., 2017). The $\mathrm{PyC}$ on the soil surface is likely to be eroded before and more preferentially than mineral soil or mineral-associated PyC, except in the cases of landslides and other major mass wasting events. Additionally, the recently formed $\mathrm{PyC}$ would not have enough time to form stabilizing physical and chemical interactions with soil minerals prior to preferential transport, as these stabilizing interactions can take years to decades to form in natural settings (Faria et al., 2015). Over time, the PyC that is not transported by erosion is mobilized downward into the profile via dissolution, leaching, and biological processes that render it more susceptible to in-solution transport with flowing water (Güereña et al., 2015). However, the PyC that remains on the soil surface is exposed to wetting- and drying-cycles that are likely to render it more susceptible to leaching losses, although some research has indicated that the material left after leaching may be less easily decomposed (Naisse et al., 2015).

Among the most important physical and chemical properties of PyC that make it susceptible to erosion are its low density compared with soil minerals (Brewer et al., 2014), its hydrophobic properties when formed at lower $\left(<\sim 250^{\circ} \mathrm{C}\right)$ charring temperatures (Sander and Pignatello, 2005; Bodí et al., 2011), and its aromatic content and aromatic condensation (Preston and Schmidt, 2006). Generally, it is assumed that the low density $\left(<1 \mathrm{Mg} \mathrm{m}^{-3}\right)$ and hydrophobic properties of PyC allow for flotation and lateral transport of $\mathrm{PyC}$ with flowing water (Rumpel et al., 2006, 2009). The slow wetting and filling of the pores of $\mathrm{PyC}$ with water, however, should increase its density (Gray et al., 2014) and reduce its potential for flotation and transport with overland flow. Furthermore, the breakdown of $\mathrm{PyC}$ also depends on density of the $\mathrm{PyC}$ and on associations between PyC and non-pyrogenic SOM (Zimmermann et al., 2012; Pyle et al., 2017). The duration, intensity, and frequency of storm events also plays a significant role in controlling the wetting of $\mathrm{PyC}$, as the hydrophobic properties of $\mathrm{PyC}$ can only delay wetting, not prevent it entirely (Bodí et al., 2011).

\section{Climate and Hydrology}

The process of water-driven soil erosion occurs though detachment of a soil particle which is transported and deposited away from the source location. During rain-driven erosion, the impact of raindrops breaks down aggregates on the soil surface which leads to transport of soil away from the point of impact, and gravity leads to the downslope mobilization of detached particles across the soil surface (Kinnell, 2005). With all other erosion-driving factors held equal, the intensity of precipitation is the leading driver of erosion and runoff (Renard et al., 1997). Large storms are generally thought to drive the major erosion events within a landscape; however, intermediate storms can also mobilize significant amounts of material over the course of a year (Wischmeier, 1962). In addition to intense storms, rapid snowmelt and rain-on-snow events are important drivers of rapid runoff (Pierson et al., 2001). The loss or reduction of vegetation cover due to fires creates the opportunity for raindrops to reach the soil surface at high velocity, without being slowed down by aboveground vegetation and overlying litter layers. Hence, the same amount or intensity of rainfall can mobilize more $\mathrm{PyC}$, and bulk $\mathrm{C}$, from soil post-fire than it would under unburned conditions if there is loss of vegetation or litter layers (Inbar et al., 1998; Beyers et al., 2005; Cerdà and Doerr, 2005; Pierson et al., 2008, 2009, 2013). Generally, low intensity precipitation events drive preferential transport of light carbonaceous material (higher enrichment ratios, higher concentration of C) (Schiettecatte et al., 2008; Wang et al., 2010). However, during high intensity or longer duration rainfall events, a mixture of mineral material along with SOM, including pyrogenic carbon, is mobilized from the soil surface or even deeper soil horizons (large rainfall events lead to scouring of the surface or river banks or creation of deep rills and gullies), as was observed by Stacy et al. (2015) and McCorkle et al. (2016).

\section{Geomorphology of the Landscape}

The geomorphology of a landscape can significantly impact the erosion of PyC. In particular, the steepness of a hillslope has a non-linear, direct effect on the amount of sediment transported by soil erosion, where increased gradient increases the mass of transported sediment (Montgomery and Brandon, 2002). Slope length and hillslope hydrology also likely play important roles on PyC transport, as they do in in non-fire impacted landscapes (Munro and Huang, 1997; Parsons et al., 2006; Istanbulluoglu et al., 2008), as moderate length slopes allow for the greatest transport of material, while shorter slopes are limited in space for runoff to build speed. Longer slopes have increased area for water to meet resistance and for particles to settle out, so the travel distance of particles is a function of their size.

Aspect of a hillslope can impact erosion due to its effects on plant growth, density, OM decomposition, with subsequent implications for fuel availability for fires and soil burning (Cerdà et al., 1995). The impacts of aspect on hillslope erosion can be compounded by delays in vegetation recovery, leading to longer-term enhanced erosion rates and continued loss of soil 
nutrients, and weather-related events, which can cause different erosion rates on different aspects of the same hillslope (Cerdà et al., 1995; Pierson et al., 2008, 2009). Furthermore, the location within a landscape where $\mathrm{PyC}$ is formed or deposited can be critical for the long-term fate of the PyC. If $\mathrm{PyC}$ is produced on eroding landform positions (convex or linear positions such as summit, shoulder, or back/foot slope positions), then it is more likely to be transported laterally by wind or water erosion processes, or gravity driven diffusive mass transport, compared to $\mathrm{PyC}$ produced in depositional landform positions (concave or flat positions such as toeslopes, or alluvial and colluvial plains). However, if the PyC is either formed or deposited on depositional landform positions, then it is more likely to persist in the catchment longer and be stabilized in the depositional landform positions by forming physical and/or chemical associations with soil minerals, or to get buried by subsequent erosion/deposition events that bring sediment to the depositional position as has been found for non-pyrogenic carbon (Stallard, 1998; Berhe, 2012).

\section{Interactions}

The three drivers of $\mathrm{PyC}$ erosion, fire, geomorphology, and climate, also interact with each other to control rates of $\mathrm{PyC}$ erosion (Figure 4). For example, different combinations of steepness of a hillslope, size of watershed, and intensity of precipitation may lead to differing rates of erosion (Pierson et al., 2001). Generally, climate describes the expected precipitation events, but local scale variations in weather, such as exceptionally large precipitation events, can drive the formation of rills or gullies and large mass wasting events. Furthermore, landscapes with very steep slopes, which could predispose a landscape to mass wasting events, could further enhance these large movement events. As another example, long-term climate patterns impact the type and amount of vegetation available as fuel for fire, which could further impact the quality and quantity of PyC left behind after fire. The amount and nature, such as density and water content, of available fuel play an import role in determining the intensity of fire, which controls the resulting PyC properties, such as aromatic content and aromatic condensation, as demonstrated by laboratory studies (Mimmo et al., 2014; Pyle et al., 2015; Wiedemeier et al., 2015). This more condensed PyC produced at higher temperatures is more susceptible to flotation and theoretically more susceptible to erosive forces (Brewer et al., 2014).

\section{Implications of Including Erosion as a PyC Flux Term}

While the magnitude of PyC transported by soil erosion has not been fully determined, some estimate that this flux is on the order of 29-87 Tg PyC per year (Bird et al., 2015). Current evidence suggests that erosion is a significant driver of $\mathrm{PyC}$ redistribution in hillslopes (i.e., loss from soil profiles of eroding landform positions, that may or may not remain in the same catchment as input to the soil profiles of depositional landform positions; Rumpel et al., 2006, 2009; Abney et al., 2017). Environmental conditions post-fire and the nature of $\mathrm{PyC}$ lead to elevated rates of erosion and enrichment of $\mathrm{PyC}$ within the resulting eroded

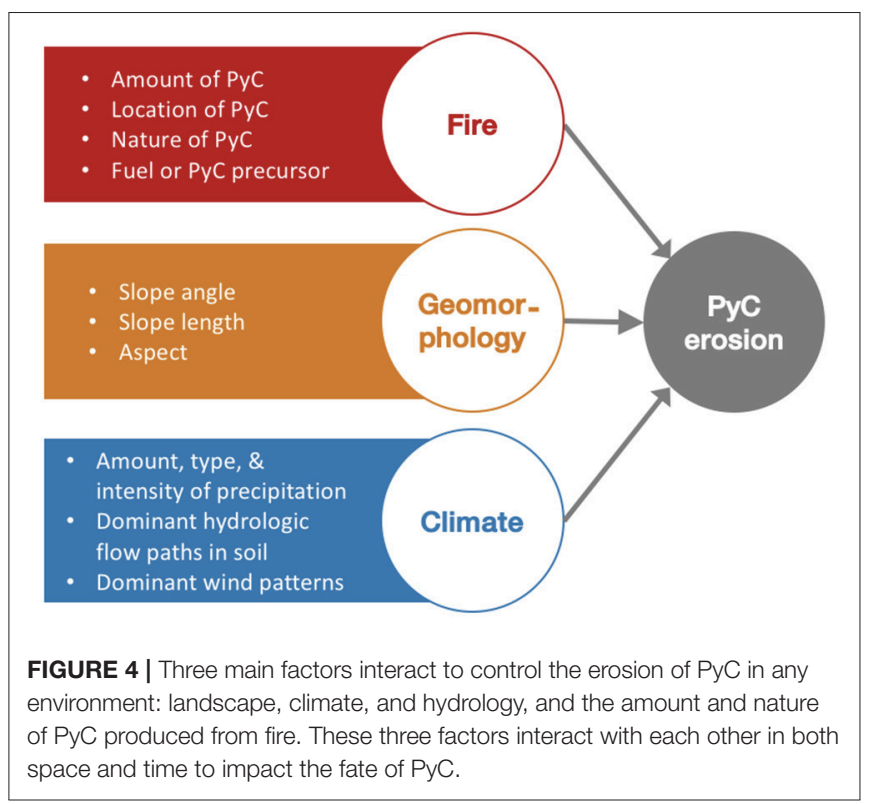

sediments (Pierson et al., 2008; Rumpel et al., 2009). The large flux of PyC to oceans (Jaffé et al., 2013) is further indication that there is considerable transport of dissolved and particulate forms of PyC within the terrestrial and to the aquatic system. An approach that considers the geomorphologic and biogeochemical cycling changes associated with fires is needed to quantify stock and erosional fluxes of PyC in fire-affected dynamic landscapes and to determine how and why erosional distribution of PyC could affect our understanding of the dynamics of both bulk SOM and $\mathrm{PyC}$ in the terrestrial biosphere.

\section{Calculating Loss and MRT of PyC}

One of the most common and simplest approaches to estimating PyC MRT is based on calculations of a loss rate from a given reservoir (i.e., soil) using simple one-pool box model approaches. Turnover time $(T)$ is assumed to be equivalent to the inverse of the loss rate constant $(k)$, with the assumption of steady state. Turnover time is imposed on a first-order kinetic model of PyC dynamics as:

$$
T=1 / k
$$

where,

$$
d P y C / d t=I_{P y C}-k \times P y C
$$

where $T$ is turnover time (years), $k$ is a loss rate constant (as a proportion of the PyC stock, $\mathrm{yr}^{-1}$ ), $P y C$ is stock of $\mathrm{PyC}$ in a soil pool $\left(\mathrm{g} / \mathrm{m}^{2}\right), I_{P y C}\left(\mathrm{~g} \mathrm{~m}^{-2} \mathrm{yr}^{-1}\right)$ is the rate of PyC input to the reservoir. This model assumes a single rate of loss of $\mathrm{PyC}$ that is solely comprised of decomposition, and a uniform input of $\mathrm{PyC}$ across the ecosystem. Below we argue for the role of erosion as a significant loss factor for $\mathrm{PyC}$ and demonstrate the error in MRT calculations when erosion is ignored using a specific case study. 


\section{Estimating MRT of PyC in Dynamic Landscapes}

Ignoring the contribution of erosion to soil PyC stocks can lead to errors in both the stock as well as estimated turnover time of PyC in dynamic landscapes. Many fires occur in areas that are prone to erosion, but even if an erosional loss term of PyC is included, the role of erosion as a gain term (in depositional landform positions) is not yet accounted for within soil PyC budget models, and rarely accounted for in field studies (Abney et al., 2017). Not accounting for this gain of $\mathrm{PyC}$ can lead to major errors within our budget models of $\mathrm{PyC}$ and $\mathrm{C}$ within eroding landscapes. We have considered three landform positions or types in the following model: (1) a landform where no sediment material is being transported to or from that area; (2) an eroding landform position (e.g., shoulder, backslope), where erosion represents a loss term for PyC; and (3) a depositional landform position (e.g., toeslope or plain), where deposition of $\mathrm{PyC}$ eroded from upslope positions leads to input of PyC. Following works of Stallard (1998) and Berhe et al. (2008) on erosional redistribution of bulk SOM, here, a model for first order $\mathrm{C}$ kinetics was modified to assess the potential effect of erosion on PyC dynamics. The firstorder loss rate constant $(k)$ in the first order model (Equation 2) was replaced with two separate constants for decomposition $\left(k_{o}\right)$ and erosional redistribution $\left(k_{e},\right)$, where $k=k_{o}+k_{e}$ as:

$$
\mathrm{dPyC} / \mathrm{dt}=I-\left(k_{0}+k_{e}\right) \times P y C
$$

where $P y C=$ soil PyC stock $\left(\mathrm{g} \mathrm{m}^{-2}\right) ; I=$ soil pyrogenic carbon inputs $\left(\mathrm{g} \mathrm{m}^{-2} \mathrm{yr}^{-1}\right) ; k_{o}=$ first-order loss of PyC by abiotic or biological decomposition $\left(\mathrm{yr}^{-1}\right)$; and $k_{e}=$ first-order loss of PyC by erosion $\left(\mathrm{yr}^{-1}\right)$. This $k_{e}$ term describes the different trajectories of $\mathrm{PyC}$ at eroding or depositional landform positions and accounts for additions or losses of PyC via erosional processes. Additionally, in the depositional landform position, there is both a loss of PyC initially deposited that is a function of the stock of $\mathrm{PyC}$ in that landform position (Equation 4). There is also an increase in $\mathrm{PyC}$ stock in the depositional landform position due to the input from erosion, $k_{e}=$ first-order gain of $\mathrm{PyC}$ by erosion $\left(\mathrm{yr}^{-1}\right)$ which is a function of the $\mathrm{PyC}$ stock in the corresponding eroding landform position, $P y C_{\text {ero }}=$ eroding soil PyC stock $\left(\mathrm{g} \mathrm{m}^{-2}\right)$ :

$$
\mathrm{dPyC} / \mathrm{dt}=I-\left(k_{0} \times P y C\right)+\left(k_{e} \times P y C_{e r}\right)
$$

For our model calculations, we used published results from Hammes et al. (2008) where they measured PyC stock in chernozem soils at a steppe preserve in Russia as a case study. The soils were sampled twice over about 100 years, first between 1895 and 1903, and then in 1997 and 2004. The authors then used the difference in PyC stock (measured using the BPCA marker technique) of the soil between the two time periods and radiocarbon measurements of SOM to derive MRT of PyC in soil using a one $\mathrm{PyC}$ pool, first-order decay (i.e., linear, donor-controlled) model (Hammes et al., 2008). Though, this study does not account for any leaching or erosion of $\mathrm{PyC}$ that could have occurred between the two sampling points. In our calculations, we assumed the soils had initial soil PyC stock of $2.5 \mathrm{~kg} \mathrm{PyC} / \mathrm{m}^{2}$ (Hammes et al., 2008) and a relatively low decomposition constant $\left(k_{o}\right)$ for PyC of $0.4 \% / y e a r$, which approximates a turnover time of 250 years (Hammes et al., 2008). Then, we considered erosion or deposition as loss or gain terms, as shown in Equations (3) and (4). We calculated the stock of PyC in the non-erosion (flat) position by assuming that $k=k_{0}$ and that $k_{e}=0$. For the eroding position $k_{e}$ represents a loss term for $\mathrm{PyC}$, while for the depositional position it represents a gain to the existing PyC stock. The depositional area has erosional inputs of PyC that maintain a higher PyC stock through the simulation. The eroding area has both erosion and decomposition acting together to remove PyC from the soil, so it has the lowest PyC stock at the end of the 150-year simulation (Figure 5).

This model scenario is an inherently simplified version of PyC dynamics within eroding hillslopes, and thus operates under several assumptions. This model assumes a single input of PyC, an initial even distribution and availability of PyC for erosional transport, and a landscape comprised of depositional and eroding landform positions. In real landscapes, landform positions can act as both eroding and depositional sites, such as flat locations that would serve as depositional sites can be susceptible to wind erosion (Pyle et al., 2017). However, depending on specific fire and environmental conditions, this model may still hold as a proximate estimation for the erosion

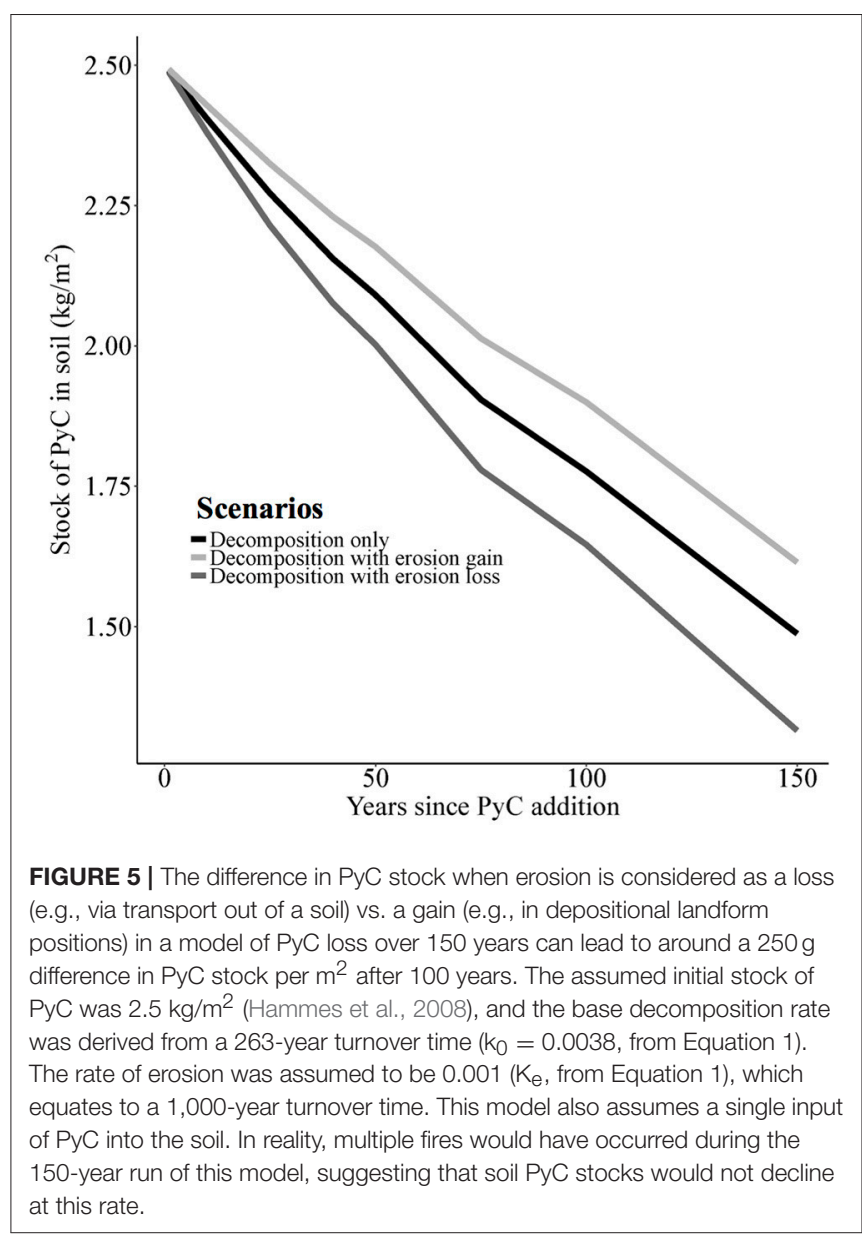


inputs of PyC into a depositional landform position, particularly as recent research has demonstrated the preferential erosion of PyC on even apparently flat landscapes (Pyle et al., 2017). This model assumes only a single fire event to input PyC, but in many environments, it is likely that there would be more than a single input of PyC over the duration of 150 years. This model also assumes a linear and constant rate of erosion, which is not likely to occur in natural ecosystem. However, this model estimation demonstrates the possible order of magnitude error that might be found in post-fire erodible landscapes, assuming similar initial stocks and losses via erosion and decomposition. We found that, for the specific conditions we considered, not accounting for erosional redistribution of $\mathrm{PyC}$ can lead to almost $300 \mathrm{~g} \mathrm{PyC} \mathrm{m}^{-2}$ difference between the maximum gain of $\mathrm{PyC}$ stock from depositional of eroded material and minimum erosion loss scenarios over a 150-year simulation. Note that the model presented here is inherently simplistic by design, as it is aiming to demonstrate the role of soil erosion under three landform positions. In any given hillslope, the actual role of erosional redistribution depends on the nature of the landscape, rate of $\mathrm{PyC}$ input, and the environmental variables that control rate of PyC loss through decomposition, leaching, and/or erosion. For example, future models could be designed for specific environments to include additional fluxes of PyC that have yet to be well quantified, such as bioturbation, leaching, and subsequent fires, and likely control its stock and residence time in the soil.

The model presented above can also be used to determine the effect of erosion on mean residence times or persistence of PyC in soil. The more that erosion contributes to the $k$ term as a loss of $\mathrm{PyC}$, the larger the overall $k$ term and the faster the turnover of $\mathrm{PyC}$ in a soil, since a portion of the PyC stock would be moved to downslope positions. Conversely, for depositional landform positions, the $k_{e}$ adds to the soil profile's PyC stock, and because $k_{e}$ would be negative in this case, it lowers the effective $k$ term in Equation (1), leading to longer turnover times for $\mathrm{PyC}$ in soil profiles of depositional landform positions.

On the local scale, explicitly considering erosion as a loss or gain term (depending on the landform positions considered) for $\mathrm{PyC}$ in dynamic landscapes leads to considerable differences in MRT at different geomorphic landform positions. Across even a single hillslope, soil properties and controls on decomposition vary considerably. We calculated turnover times for eroding and depositional landform positions, by assuming a decomposition rate $\left[k_{0}\right.$ from Equation 3 of $0.04 \%$ /year and an erosion rate of $0.01 \%$ /year (1,000-year turnover time from erosion processes alone)]. This calculation also assumes that $\mathrm{PyC}$ that is eroded and left in place is similarly impacted by decomposition, which is not necessarily true based on preferential erosion of PyC (Rumpel et al., 2009). Under natural conditions, a considerable proportion of $\mathrm{PyC}$ eroded in the short term (up to 1 year) post-fire is likely mobilized further through the landscape on longer $(10+$ years $)$ timescales (Abney et al., 2017).

In this simple model, the erosion rate $\left(k_{e}\right)$ was positive for the eroding landform position (indicating erosional loss of $\mathrm{PyC}$ from eroding landform positions and making net loss of PyC faster) and negative for the depositional landform position (indicates an addition of $\mathrm{PyC}$ and decreasing the net loss of $\mathrm{PyC}$ ). This erosion rate was further divided into five different fractions, such that $0 \%$ indicates no erosion, or no erosion accounted for, and $100 \%$ indicates $100 \%$ of the $0.01 \%$ erosion rate accounted for within the model. We found that if $100 \%$ of this theoretical erosion rate is accounted for, then the difference in calculated turnover time is $\sim 150$ years (Figure 6). If $50 \%$ of the erosional loss of $\mathrm{PyC}$ from a soil is accounted for, then the difference between the maximum turnover time with erosion as a gain and the minimum turnover time with erosion as a loss is $\sim 70$ years. If the erosion rate were higher (i.e., the theoretical $100 \%$ erosion was a higher background erosion rate), then this difference in turnover time would be even greater. This difference in erosion indicates that over the scale of a landscape, local topographical differences that determine whether $\mathrm{PyC}$ is eroded or deposited over time can play a major role in the fate of that $\mathrm{PyC}$, depending on the relative rates of loss, deposition, and burial of PyC.

This model only applies to the fate $\mathrm{PyC}$ that remains on the surface soils, which is the fraction that is likely to experience erosion. The fraction of soil PyC that is found in deep soil layers or gets buried overtime is not likely to experience significant lateral redistribution with erosion, and hence is not included in this discussion. Also, the importance of the role of erosion as a gain or a loss term is also dependent on the relative role of erosion in each landscape (Figure 6), as different landscape geomorphologies can lead to drastically different erosional rates and processes (section Geomorphology of the

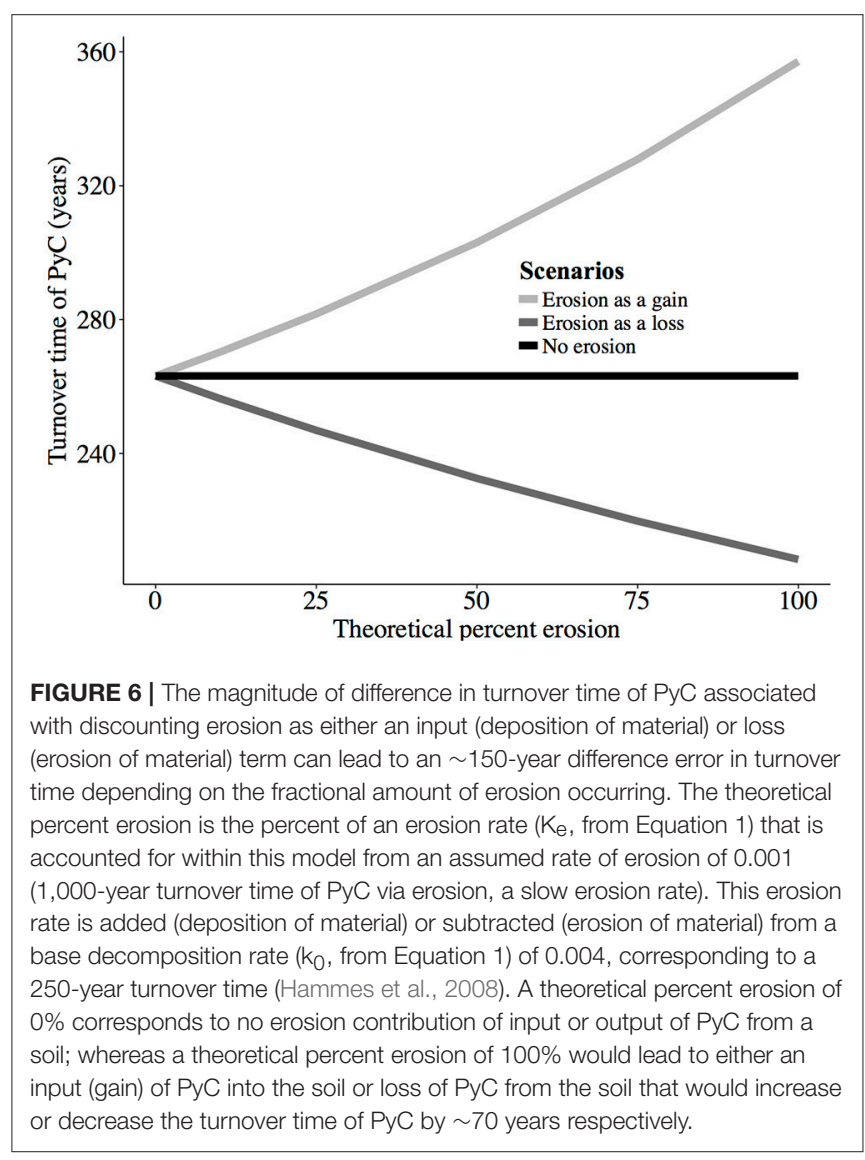


Landscape). Furthermore, the intensity, type, and timing of postfire precipitation play important roles in controlling the rate of PyC water-driven erosion (Hammes et al., 2008) and transport of other soil constituents (i.e., reactive minerals) that may influence the fate of PyC post-erosion and/or deposition.

\section{Explicitly Considering Erosion in Global PyC Budgets}

The role of erosion in redistributing $\mathrm{PyC}$ can also impact global models of PyC cycling and storage (Bird et al., 2015). The major global stocks of PyC are $1.05 \times 10^{15} \mathrm{~g}$ PyC in the soil (Bird et al., 2015), $9.87 \times 10^{18} \mathrm{~g}$ PyC in the ocean (Ziolkowski and Druffel, 2010), and $1.79 \times 10^{22} \mathrm{~g} \mathrm{PyC}$ in marine sediments (Masiello, 1998). The major fluxes of $\mathrm{PyC}$ are decomposition, which ranges from 0.25 to $20 \%$ loss per year depending on PyC properties and environment (Table 1), 1\% loss per year from leaching and percolation (Major et al., 2010; Abiven et al., 2011), $7.4 \times 10^{12}$ $\mathrm{g}$ PyC per year transported to oceans by rivers (Dittmar et al., 2012; Jaffé et al., 2013), and 0.02\% loss of ocean PyC to sediment per year (Masiello, 1998).

Current global and smaller-scale literature is not fully accounting for the erosion of $\mathrm{PyC}$ and transformations of $\mathrm{PyC}$ during and after erosion throughout the global ecosystem, even though the stocks are in approximate steady state (Bird et al., 2015). This indicates that while preferential loss of PyC via erosion may serve as a significant loss mechanism for $\mathrm{PyC}$, it is also likely acting as a stabilization mechanism of $\mathrm{PyC}$ for the budget to remain roughly in balance. Furthermore, uncertainties also remain concerning the role of erosional transport in physical breakdown and decomposition of $\mathrm{PyC}$ during erosional transport. In the landform position model presented here, the rate of decomposition during erosional transport was assumed the same as non-pyrogenic carbon, although there is considerable evidence that this is not likely the case (Santos et al., 2012; Whitman et al., 2014). Since this assumption would likely prove invalid and $\mathrm{PyC}$ decomposition during erosion is considerably lower, this would have important implications for the long-term stabilization of PyC. Moreover, this model also assumes a steady state of erosion and even distribution and formation of PyC across the landscape, which is not representative of the heterogeneous nature of fire. Finally, even though erosion of $\mathrm{PyC}$ from slopes represents a loss process, it serves the opposite role when the $\mathrm{PyC}$ is buried in depositional landform positions. If we assume that erosional redistribution, and subsequent burial of eroded $\mathrm{PyC}$ in depositional soil profiles can effectively reduce its decomposition rate, then the process of soil erosion can potentially be a stabilization mechanism for PyC in dynamic landscapes (Berhe et al., 2007; Berhe and Kleber, 2013). Future research should investigate the long-term fate of PyC that is eroded and buried, and the magnitude that this can serve as a mechanism for increased soil C storage.

The models presented here do not necessarily represent natural variation in timing and magnitude of fire, erosion, and future climates that may alter the global PyC cycle, particularly as large erosion and fire events are strongly controlled by local climatic conditions (Westerling et al., 2006). The loss of PyC from the soil is likely more episodic and variable in nature than these scenarios account for, and therefore this loss may be different than predicted by constant rate functions used in this model. Also, these calculations do not account for the decomposition or loss of PyC from groundwater or through leaching.

In addition to the limited knowledge of the controls on breakdown of $\mathrm{PyC}$ in the soil system, it is widely agreed that the laboratory-based incubation studies are over-estimating the rate of $\mathrm{PyC}$ decomposition due to the disturbance of the soil and since decomposition conditions are considered to be more optimal in the laboratory compared with field conditions. Many of the laboratory based estimates are over 10\% PyC loss per year (Nguyen et al., 2010; Foereid et al., 2011), which is inconsistent with calculated PyC MRT measurements that range from several hundred years to several millennia (Hammes et al., 2008; Lehmann et al., 2008; Singh et al., 2012; Bird et al., 2015). It is also possible that erosional deposition and burial of $\mathrm{PyC}$ is a more significant process for the long-term stabilization of $\mathrm{PyC}$ than previously considered. If erosion is playing a significant role in the stabilization of $\mathrm{PyC}$ and if decomposition rates of $\mathrm{PyC}$ are consistently over-estimated, this could have major implications for global models of PyC cycling and storage (Bird et al., 2015). Parameterizing global stocks and fluxes of $\mathrm{PyC}$ is critical, because PyC could be serving a major role that has so far not been accounted properly in global C budgets (Lehmann, 2007; Santín et al., 2015).

While current box models, such as in Bird et al. (2015), suggest that erosion is playing a role in redistributing $\mathrm{PyC}$ and a role in burying it for longer-term storage within the soil system, these models are a simplification of the global PyC cycle that do not include quantitative inputs such as type of erosion, climate data, and topography, which are critical for determining the effects of erosion on PyC turnover times and persistence. What can conclusively be drawn from the model scenarios presented here is that the role of erosion of PyC should not be ignored as a factor controlling its long-term fate within the soil and that further research is needed to quantitatively describe and realize the variability in these systems.

\section{Remaining Uncertainties in PyC Erosion and Recommendations for Future Research}

The variation in the estimates of loss of PyC reflects both the spectrum of methodologies used to measure $\mathrm{PyC}$ and the lack of inclusion of erosion and other processes, such as leaching, as loss mechanisms. The dynamics of PyC within the soil system depends on prevalent environmental conditions, such as temperature, precipitation, land use, slope, aspect, and vegetation. Available data on the magnitude of loss of PyC from the soil by different processes is currently incomplete, and has a lot of uncertainty, making model parameterization very difficult (see Table 1 for published magnitudes of fluxes of PyC). In particular, the rates of erosion and burial of $\mathrm{PyC}$ and the mechanisms and magnitude of the transport of $\mathrm{PyC}$ from land to water need further investigation (Bird et al., 2015; Santín et al., 
2016), particularly in ecosystems that are susceptible to erosion, such as upland temperate forests.

One of the major challenges in quantifying PyC fluxes within the environment is that no single analytical technique can measure the range of materials that make up $\mathrm{PyC}$ continuum, including soot, charcoal, and charred biomass (Masiello, 2004). Many different techniques (e.g., physical separation, nuclear magnetic resonance spectroscopy, mid-infrared spectroscopy, benzene polycarboxylic acid, mid-infrared spectroscopy, and partial least squares regression) are currently being used to measure $\mathrm{PyC}$ concentration and composition (Schmidt and Noack, 2000; Gustafsson et al., 2001; Masiello, 2004; Preston and Schmidt, 2006; Hammes et al., 2007; De La Rosa et al., 2008; Wiedemeier et al., 2013, 2015; Cotrufo et al., 2016), with varying degrees of accuracy for quantifying different types of compounds in the PyC continuum (Masiello, 2004; Hammes et al., 2007). Due to the variety of techniques currently used, and a lack of meaningful standardization methods for the different techniques, direct comparison of published results is extremely difficult. Many PyC-like, aromatic materials can be confounded with $\mathrm{PyC}$ in some of these techniques, further adding error to these analyses, along with some of them having varying degrees of sensitivity to aromatic condensation (Skjemstad et al., 1999). Hence, the data and arguments presented above are based on the most conservative results and least contradictory conclusions that we could draw from published literature.

In the simple decay model presented here (Figure 5), in the absence of new input, the soil's PyC stocks were declining considerably lower than the current PyC soil stock measurements would suggest. It is likely that the inferred or measured rates of PyC loss in soils are overestimating the effectiveness of microbial decomposition, especially for the studies generated from shortterm laboratory experiments conducted under ideal climate and environmental conditions, especially since some research has indicated an initial priming effect with the addition of PyC (Zimmerman et al., 2011). In longer-term laboratory incubations and models, rates of PyC decomposition are considerably lower and are generally non-linear (Kuzyakov et al., 2009; Foereid et al., 2011), in contrast to the linear the model presented here. Future modeling efforts should focus on the temporal variability in inputs of $\mathrm{PyC}$ into the soil in addition to the role of erosion as both and input and loss process for PyC.

\section{CONCLUSIONS}

Interactions of environmental perturbations such as fire and erosion can play significant roles in regulating $\mathrm{PyC}$ and SOM persistence in dynamic landscapes. The synthesis of published results and the model presented here illustrates how not accounting for integrated dynamic decomposition and

\section{REFERENCES}

Abiven, S., Hengartner, P., Schneider, M. P. W., Singh, N., and Schmidt, M. W. I. (2011). Pyrogenic carbon soluble fraction is larger and more aromatic geomorphological processes can lead to significant errors in our current understanding of $\mathrm{PyC}$ dynamics in the terrestrial ecosystem. Specifically, not accounting for post-fire erosion could lead to significant differences in projected stocks and turnover times of $\mathrm{PyC}$ within the soil, depending on specific ecosystem properties such as erosion and decomposition rates. These differences in stock and turnover time vary based on landform position, rates and drivers of erosion, among other factors.

Understanding the long-term fate of terrestrial $\mathrm{OM}$ and $\mathrm{PyC}$ is critical for generating accurate models and to better manage these ecosystems to maximize soil $\mathrm{C}$ storage. Considering climate change, understanding the controls on the $\mathrm{PyC}$ cycle may become ever more critical for managing soil $\mathrm{C}$ cycle. This is particularly relevant as the relative roles of fire and erosion as controlling forces of the soil PyC cycle may act in different ways under altered climatic regimes and across different ecosystems and regions. $\mathrm{PyC}$ is an important component of the global $\mathrm{C}$ cycle that is being assessed for its potential to account for the missing $\mathrm{C}$ sink and biochar addition to soil is being discussed as one of many approaches that can be used to mitigate climate change (Lehmann, 2007). It is critically important for future research to focus on more quantitative understanding of the production, stocks and major loss processes for PyC from the soil, including decomposition, erosion, leaching, and consumption in subsequent fires. However, currently, the uncertainties in comparing loss rates from different ecosystems and measurement techniques make global synthesis difficult, in addition to uncertainties in current stock estimates. Moreover, major gaps remain in our understanding of the mechanisms and magnitude of PyC loss from the soil system, and it is likely that erosional redistribution of $\mathrm{PyC}$ post-fire plays a major role in controlling the fate of PyC in the soil system.

\section{AUTHOR CONTRIBUTIONS}

All authors listed have made a substantial, direct and intellectual contribution to the work, and approved it for publication.

\section{FUNDING}

Funding for this work was provided from the National Science Foundation (CAREER EAR-1352627) award to AAB.

\section{ACKNOWLEDGMENTS}

The authors gratefully acknowledge Caroline Masiello, Fernanda Santos, Stephen Hart, Marilyn Fogel, and Jonathan Sanderman for their helpful and detailed comments on earlier versions of this manuscript. 
of soil organic carbon. Front. Earth Sci. 5:99. doi: 10.3389/feart.2017. 00099

Al-Hamdan, O. Z., Pierson, F. B., Nearing, M. A., Williams, C. J., Stone, J. J., Kormos, P. R., et al. (2012). Concentrated flow erodibility for physically based erosion models: temporal variability in disturbed and undisturbed rangelands. Water Resour. Res. 48:W07504. doi: 10.1029/2011WR011464

Albalasmeh, A. A., Berli, M., Shafer, D. S., and Ghezzehei, T. A. (2013). Degradation of moist soil aggregates by rapid temperature rise under low intensity fire. Plant Soil 362, 335-344. doi: 10.1007/s11104-012-1408-z

Andela, N., Morton, D. C., Giglio, L., Chen, Y., van der werf, G. R., Kasibhatla, P. S., et al. (2017). A human-driven decline in global burned area. Science 356, 1356-1362. doi: 10.1126/science.aal4108

Araya, S. N., Fogel, M. L., and Berhe, A. A. (2017). Thermal alteration of soil organic matter properties: a systematic study to infer response of Sierra Nevada climosequence soils to forest fires. Soil 3, 31-44. doi: 10.5194/soil-3-31-2017

Avnimelech, Y., and McHenry, J. (1984). Enrichment of transported sediments with organic carbon, nutrients, and clay. Soil Sci. Soc. Am. J. 48, 259-266. doi: 10.2136/sssaj1984.03615995004800020006x

Baker, V. R. (1988). "Flood erosion," in Flood Geomorphology, ed V. R. Baker (New York, NY: John Wiley \& Sons), 81-95.

Battin, T., Luyssaert, S., Kaplan, L., Aufdenkampe, A., Richter, A., and Tranvik, L. (2009). The boundless carbon cycle. Nat. Geosci. 2, 598-600. doi: $10.1038 /$ ngeo618

Benavides-Solorio, J., and MacDonald, L. H. (2001). Post-fire runoff and erosion from simulated rainfall on small plots, Colorado Front Range. Hydrol. Process. 15, 2931-2952. doi: 10.1002/hyp.383

Berhe, A. A. (2012). Decomposition of organic substrates at eroding vs. depositional landform positions. Plant Soil 350, 261-280. doi: 10.1007/s11104-011-0902-Z

Berhe, A. A., Harden, J., Torn, M., Kleber, M., Burton, S., and Harte, J. (2012). Persistence of soil organic matter in eroding vs. depositional landform positions. J. Geophys. Res. Biogeosci. 117:G02019. doi: 10.1029/2011JG001790

Berhe, A. A., Harden, J. W., Torn, M. S., and Harte, J. (2008). Linking soil organic matter dynamics and erosion-induced terrestrial carbon sequestration at different landform positions. J. Geophys. Res. Biogeosci. 113:G04039. doi: 10.1029/2008JG000751

Berhe, A. A., Harte, J., Harden, J. W., and Torn, M. S. (2007). The Significance of erosion-induced terrestrial carbon sink. Bioscience 57, 337-346. doi: 10.1641/B570408

Berhe, A. A., and Kleber, M. (2013). Erosion, deposition, and the persistence of soil organic matter: mechanistic considerations and problems with terminology. Earth Surf. Process. Landforms 38, 908-912. doi: 10.1002/esp.3408

Beyers, J. L., Brown, J. K., Busse, M. D., DeBano, L. F., Elliot, W. J., Folliott, P. F., et al. (2005). Wildland Fire in Ecosystems Effects of Fire on Soil and Water. JFSP Synthesis Reports, United States Department of Agriculture.

Bird, M. I., Wynn, J. G., Saiz, G., Wurster, C. M., and McBeath, A. (2015). The pyrogenic carbon cycle. Annu. Rev. Earth Planet. Sci. 43, 273-298. doi: 10.1146/annurev-earth-060614-105038

Bodí, M. B., Mataix-Solera, J., Doerr, S. H., and Cerdà, A. (2011). The wettability of ash from burned vegetation and its relationship to Mediterranean plant species type, burn severity and total organic carbon content. Geoderma 160, 599-607. doi: 10.1016/j.geoderma.2010.11.009

Bond, T. C., Doherty, S. J., Fahey, D., Forster, P., Berntsen, T., Deangelo, B., et al. (2013). Bounding the role of black carbon in the climate system: a scientific assessment. J. Geophys. Res. Atmos. 118, 5380-5552. doi: 10.1002/jgrd.50171

Boot, C., Haddix, M., Paustian, K., and Cotrufo, M. (2015). Distribution of black carbon in ponderosa pine forest floor and soils following the High Park wildfire. Biogeosciences 12, 3029-3039. doi: 10.5194/bg-12-3029-2015

Brewer, C. E., Chuang, V. J., Masiello, C. A., Gonnermann, H., Gao, X., Dugan, B., et al. (2014). New approaches to measuring biochar density and porosity. Biomass Bioener. 66, 176-185. doi: 10.1016/j.biombioe.2014.03.059

Brodowski, S., John, B., Flessa, H., and Amelung, W. (2006). Aggregateoccluded black carbon in soil. Eur. J. Soil Sci. 57, 539-546. doi: 10.1111/j.1365-2389.2006.00807.x

Brown, J. K., and Smith, J. K. (2000). Wildland Fire in Ecosystems: Effects of Fire on Flora. General Technical Report. RMRS-GTR-42-vol. 2, US Department of Agriculture, Forest Service, Rocky Mountain Research Station, Ogden, UT.
Cain, M. L., Subler, S., Evans, J. P., and Fortin, M. J. (1999). Sampling spatial and temporal variation in soil nitrogen availability. Oecologia 118, 397-404. doi: $10.1007 / \mathrm{s} 004420050741$

Campbell, J., Donato, D., Azuma, D., and Law, B. (2007). Pyrogenic carbon emission from a large wildfire in oregon, United States. J. Geophys. Res. Biogeosci. 112:GO4014. doi: 10.1029/2007JG000451

Carroll, E. M., Miller, W. W., Johnson, D. W., Saito, L., Qualls, R. G., and Walker, R. F. (2007). Spatial analysis of a large magnitude erosion event following a Sierran Wildfire. J. Environ. Qual. 36, 1105-1105. doi: 10.2134/jeq2006.0466

Cerdà, A., and Doerr, S. H. (2005). Influence of vegetation recovery on soil hydrology and erodibility following fire: an 11-year investigation. Int. J. Wildland Fire 14, 423-437. doi: 10.1071/WF05044

Cerdà, A., Imeson, A., and Calvo, A. (1995). Fire and aspect induced differences on the erodibility and hydrology of soils at La Costera, Valencia, southeast Spain. Catena 24, 289-304. doi: 10.1016/0341-8162(95)00031-2

Certini, G. (2005). Effects of fire on properties of forest soils: a review. Oecologia 143, 1-10. doi: 10.1007/s00442-004-1788-8

Chaopricha, N. T., and Marín-Spiotta, E. (2014). Soil burial contributes to deep soil organic carbon storage. Soil Biol. Biochem. 69, 251-264. doi: 10.1016/j.soilbio.2013.11.011

Chapin, F., Woodwell, G., Randerson, J., Rastetter, E., Lovett, G., Baldocchi, D., et al. (2006). Reconciling carbon-cycle concepts, terminology, and methods. Ecosystems 9, 1041-1050. doi: 10.1007/s10021-005-0105-7

Cope, M., and Chaloner, W. (1980). Fossil charcoal as evidence of past atmospheric composition. Nature 283, 647-649. doi: 10.1038/283647a0

Cotrufo, M. F., Boot, C., Abiven, S., Foster, E. J., Haddix, M., Reisser, M., et al. (2016). Quantification of pyrogenic carbon in the environment: an integration of analytical approaches. Org. Geochem. 100, 42-50. doi: 10.1016/j.orggeochem.2016.07.007

Czimczik, C. I., and Masiello, C. A. (2007). Controls on black carbon storage in soils. Glob. Biogeochem. Cycles 21:GB3005. doi: 10.1029/2006GB002798

DeBano, L. F. (2000). The role of fire and soil heating on water repellency in wildland environments a review. J. Hydrol. 231, 195-206. doi: 10.1016/S0022-1694(00)00194-3

DeBano, L. F., Neary, D. G., and Ffolliott, P. F. (1998). Fire's Effects on Ecosystems. New York, NY: John Wiley and Sons.

De La Rosa, J. M., González-Pérez, J. A., González-Vázquez, R., Knicker, H., López-Capel, E., Manning, D., et al. (2008). Use of pyrolysis/GCMS combined with thermal analysis to monitor $\mathrm{C}$ and $\mathrm{N}$ changes in soil organic matter from a Mediterranean fire affected forest. Catena 74, 296-303. doi: 10.1016/j.catena.2008.03.004

Dittmar, T., De Rezende, C. E., Manecki, M., Niggemann, J., Ovalle, A. R. C., Stubbins, A., et al. (2012). Continuous flux of dissolved black carbon from a vanished tropical forest biome. Nat. Geosci. 5, 618-622. doi: 10.1038/ngeo1541

Doerr, S. H., and Thomas, A. D. (2000). The role of soil moisture in controlling water repellency: new evidence from forest soils in Portugal. J. Hydrol. 231, 134-147. doi: 10.1016/S0022-1694(00)00190-6

Doetterl, S., Berhe, A. A., Nadeu, E., Wang, Z., Sommer, M., and Fiener, P. (2016). Erosion, deposition and soil carbon: a review of process-level controls, experimental tools and models to address $\mathrm{C}$ cycling in dynamic landscapes. Earth Sci. Rev. 154, 102-122. doi: 10.1016/j.earscirev.2015. 12.005

Dyrness, C., and Norum, R. A. (1983). The effects of experimental fires on black spruce forest floors in interior Alaska. Can. J. For. Res. 13, 879-893. doi: $10.1139 / \mathrm{x} 83-118$

Faria, S., De La Rosa, J., Knicker, H., González-Pérez, J., and Keizer, J. (2015). Molecular characterization of wildfire impacts on organic matter in eroded sediments and topsoil in Mediterranean eucalypt stands. Catena 135, 29-37. doi: 10.1016/j.catena.2015.07.007

Foereid, B., Lehmann, J., and Major, J. (2011). Modeling black carbon degradation and movement in soil. Plant Soil 345, 223-236. doi: 10.1007/s11104-011-0773-3

Glaser, B. (2002). "Past anthropogenic influence on the present soil properties of anthropogenic dark earths (Terra Preta) in Amazonia (Brazil)," in Amazonian Dark Earths: Explorations in Space and Time, eds. B. Glaser and W. I. Woods (Berlin; Heidelberg: Springer-Verlag), 517-530.

Glaser, B., Balashov, E., Haumaier, L., Guggenberger, G., and Zech, W. (2000). Black carbon in density fractions of anthropogenic 
soils of the Brazilian Amazon region. Org. Geochem. 31, 669-678. doi: 10.1016/S0146-6380(00)00044-9

González-Pérez, J. A., González-Vila, F. J., Almendros, G. and Knicker, H. (2004). The effect of fire on soil organic matter-a review. Environ. Int. 30, 855-870. doi: 10.1016/j.envint.2004.02.003

Gray, M., Johnson, M. G., Dragila, M. I., and Kleber, M. (2014). Water uptake in biochars: the roles of porosity and hydrophobicity. Biomass Bioener. 61, 196-205. doi: 10.1016/j.biombioe.2013.12.010

Gregorich, E., Greer, K., Anderson, D., and Liang, B. (1998). Carbon distribution and losses: erosion and deposition effects. Soil Tillage Res. 47, 291-302. doi: 10.1016/S0167-1987(98)00117-2

Güereña, D. T., Lehmann, J., Walter, T., Enders, A., Neufeldt, H., Odiwour, H., et al. (2015). Terrestrial pyrogenic carbon export to fluvial ecosystems: lessons learned from the White Nile watershed of East Africa. Glob. Biogeochem. Cycles 29, 1911-1928. doi: 10.1002/2015GB005095

Gustafsson, Ö., Bucheli, T. D., Kukulska, Z., Andersson, M., Largeau, C., Rouzaud, J. N., et al. (2001). Evaluation of a protocol for the quantification of black carbon in sediments. Glob. Biogeochem. Cycles 15, 881-890. doi: 10.1029/2000GB001380

Hammes, K., Schmidt, M. W. I., Smernik, R. J., Currie, L. A., Ball, W. P., Nguyen, T. H., et al. (2007). Comparison of quantification methods to measure fire-derived (black/elemental) carbon in soils and sediments using reference materials from soil, water, sediment and the atmosphere. Glob. Biogeochem. Cycles 21:GB3016. doi: 10.1029/2006GB002914

Hammes, K., Torn, M. S., Lapenas, A. G., and Schmidt, M. W. I. (2008). Centennial black carbon turnover observed in a Russian steppe soil. Biogeosciences 5, 1339-1350. doi: 10.5194/bg-5-1339-2008

Harden, J. W., Berhe, A. A., Torn, M., Harte, J., Liu, S., and Stallard, R. F. (2008). Soil erosion: data say C sink. Science 320, 178-179. doi: $10.1126 /$ science. 320.5873 .178

Hatten, J. A., and Zabowski, D. (2009). Changes in soil organic matter pools and carbon mineralization as influenced by fire severity. Soil Sci. Soc. Am. J. 73, 262-273. doi: 10.2136/sssaj2007.0304

Highwood, E. J., and Kinnersley, R. P. (2006). When smoke gets in our eyes: the multiple impacts of atmospheric black carbon on climate, air quality and health. Environ. Int. 32, 560-566. doi: 10.1016/j.envint.2005.12.003

Hockaday, W. C., Grannas, A. M., Kim, S., and Hatcher, P. G. (2006). Direct molecular evidence for the degradation and mobility of black carbon in soils from ultrahigh-resolution mass spectral analysis of dissolved organic matter from a fire-impacted forest soil. Org. Geochem. 37, 501-510. doi: 10.1016/j.orggeochem.2005.11.003

Imeson, A., and Lavee, H. (1998). Soil erosion and climate change: the transect approach and the influence of scale. Geomorphology 23, 219-227. doi: 10.1016/S0169-555X(98)00005-1

Inbar, M., Tamir, M. I., and Wittenberg, L. (1998). Runoff and erosion processes after a forest fire in Mount Carmel, a Mediterranean area. Geomorphology 24, 17-33. doi: 10.1016/S0169-555X(97)00098-6

Iniguez, J., Swetnam, T., and Yool, S. (2008). Topography affected landscape fire history patterns in southern Arizona, USA. For. Ecol. Manage. 256, 295-303. doi: 10.1016/j.foreco.2008.04.023

IPCC (2013). "Summary for Policymakers," in Climate Change 2013: The Physical Science Basis, Working Group I Contribution to the Fifth Assessment Report of the Intergovernmental Panel on Climate Change, eds. T. F. Stocker, D. Qin, G.K. Plattner, M. Tignor, S. K. Allen, J. Boschung, A. Nauels, Y. Xia, V. Bex, and P. M. Midgley (Cambridge, UK; New York, NY: Cambridge University Press).

Istanbulluoglu, E., Yetemen, O., Vivoni, E. R., Gutiérrez-Jurado, H. A., and Bras, R. L. (2008). Eco-geomorphic implications of hillslope aspect: inferences from analysis of landscape morphology in central New Mexico. Geophys. Res. Lett. 35:L14403. doi: 10.1029/2008GL034477

Jacinthe, P., and Lal, R. (2001). A mass balance approach to assess carbon dioxide evolution during erosional events. Land Degr. Dev. 12, 329-339. doi: 10.1002/ldr.454

Jaffé, R., Ding, Y., Niggemann, J., Vähätalo, A. V., Stubbins, A., Spencer, R. G., et al. (2013). Global charcoal mobilization from soils via dissolution and riverine transport to the oceans. Science 340, 345-347. doi: 10.1126/science.1231476

Johnson, D., Murphy, J., Walker, R., Glass, D., and Miller, W. (2007). Wildfire effects on forest carbon and nutrient budgets. Ecol. Eng. 31, 183-192. doi: 10.1016/j.ecoleng.2007.03.003
Jurado, E., Dachs, J., Duarte, C. M., and Simó, R. (2008). Atmospheric deposition of organic and black carbon to the global oceans. Atmos. Environ. 42, 7931-7939. doi: 10.1016/j.atmosenv.2008.07.029

Kasischke, E. S., Turetsky, M. R., Ottmar, R. D., French, N. H., Hoy, E. E., and Kane, E. S. (2008). Evaluation of the composite burn index for assessing fire severity in Alaskan black spruce forests. Int. J. Wildland Fire 17, 515-526. doi: 10.1071/WF08002

Keeley, J. E. (2009). Fire intensity, fire severity and burn severity: a brief review and suggested usage. Int. J. Wildland Fire 18, 116-126. doi: 10.1071/WF07049

Kinnell, P. (2005). Raindrop-impact-induced erosion processes and prediction: a review. Hydrol. Process 19, 2815-2844. doi: 10.1002/hyp.5788

Knicker, H. (2007). How does fire affect the nature and stability of soil organic nitrogen and carbon? A review. Biogeochemistry 85, 91-118. doi: 10.1007/s10533-007-9104-4

Kozlowski, T. T., and Ahlgren, C. E. (1974). Fire and Ecosystems. New York, NY: Academic Press.

Kuzyakov, Y., Subbotina, I., Chen, H., Bogomolova, I., and Xu, X. (2009). Black carbon decomposition and incorporation into soil microbial biomass estimated by C-14 labeling. Soil Biol. Biochem. 41, 210-219. doi: 10.1016/j.soilbio.2008.10.016

Kyuma, K., Tulaphitak, T., and Pairintra, C. (1985). Changes in soil fertility and tilth under shifting cultivation. Soil Sci. Plant Nutr. 31, 227-238. doi: 10.1080/00380768.1985.10557429

Laflen, J. M., Lane, L. J., Foster, G. R., and Usda, A. R. S. (1991). WEPP: a new generation of erosion prediction technology. J. Soil Water Conserv. 46, 34-38.

Lal, R. (2003). Soil erosion and the global carbon budget. Environ. Int. 29, 437-450. doi: 10.1016/S0160-4120(02)00192-7

Lal, R. (2004). Soil carbon sequestration impacts on global climate change and food security. Science 304, 1623-1627. doi: 10.1126/science.1097396

Lehmann, J. (2007). Bio-energy in the black. Front. Ecol. Environ. 5, 381-387. doi: 10.1890/1540-9295(2007)5[381:BITB]2.0.CO;2

Lehmann, J., and Joseph, S. (2015). Biochar for Environmental Management: Science, Technology and Implementation. Milton Park: Routledge.

Lehmann, J., Liang, B., Solomon, D., Lerotic, M., Luizão, F., Kinyangi, J., et al. (2005). Near-edge X-ray absorption fine structure (NEXAFS) spectroscopy for mapping nano-scale distribution of organic carbon forms in soil: application to black carbon particles. Glob. Biogeochem. Cycles 19, 1013-1025. doi: $10.1029 / 2004$ GB002435

Lehmann, J., Skjemstad, J., Sohi, S., Carter, J., Barson, M., Falloon, P., et al. (2008). Australian climate-carbon cycle feedback reduced by soil black carbon. Nat. Geosci. 1, 832-835. doi: 10.1038/ngeo358

Liu, S., Bliss, N., Sundquist, E., and Huntington, T. (2003). Modeling carbon dynamics in vegetation and soil under the impact of soil erosion and deposition. Glob. Biogeochem. Cycles 17:1074. doi: 10.1029/2002GB002010

MacDonald, L. H., Sampson, R. W., and Anderson, D. M. (2001). Runoff and road erosion at the plot and road segment scales, St John, US Virgin Islands. Earth Surface Process. Landforms 26, 251-272. doi: 10.1002/1096-9837(200103)26:3<251::AID-ESP173>3.0.CO;2-X

Major, J., Lehmann, J., Rondon, M., and Goodale, C. (2010). Fate of soil-applied black carbon: downward migration, leaching and soil respiration. Glob. Chang. Biol. 16, 1366-1379. doi: 10.1111/j.1365-2486.2009.02044.x

Marín-Spiotta, E., Chaopricha, N. T., Plante, A. F., Diefendorf, A. F., Muller, C. W., Grandy, S., et al. (2014). Long-term stabilization of deep soil carbon by fire and burial during early Holocene climate change. Nat. Geosci. 7, 428-432. doi: 10.1038/ngeo2169

Masiello, C. (2004). New directions in black carbon organic geochemistry. Mar. Chem. 92, 201-213. doi: 10.1016/j.marchem.2004.06.043

Masiello, C. A. (1998). Black carbon in deep-sea sediments. Science 280, 1911-1913. doi: 10.1126/science.280.5371.1911

Masiello, C. A., and Louchouarn, P. (2013). Fire in the Ocean. Science 340, 287-288. doi: $10.1126 /$ science. 1237688

Mataix-Solera, J., Cerda, A., Arcenegui, V., Jordan, A., and Zavala, L. M. (2011). Fire effects on soil aggregation: a review. Earth Sci. Rev. 109, 44-60. doi: 10.1016/j.earscirev.2011.08.002

McCorkle, E. P., Berhe, A. A., Hunsaker, C. T., Johnson, D. W., Macfarlane, K. J., Fogel, M. L., et al. (2016). Tracing the source of soil organic matter eroded from temperate forest catchments using carbon and nitrogen isotopes. Chem. Geol. 445, 172-184. doi: 10.1016/j.chemgeo.2016.04.025 
Miller, M. E., Bowker, M. A., Reynolds, R. L., and Goldstein, H. L. (2012). Post-fire land treatments and wind erosion-lessons from the Milford Flat Fire, UT, USA. Aeolian Res. 7, 29-44. doi: 10.1016/j.aeolia.2012.04.001

Mimmo, T., Panzacchi, P., Baratieri, M., Davies, C., and Tonon, G. (2014). Effect of pyrolysis temperature on miscanthus (Miscanthus $\times$ giganteus) biochar physical, chemical and functional properties. Biomass Bioener. 62, 149-157. doi: 10.1016/j.biombioe.2014.01.004

Montgomery, D. R., and Brandon, M. T. (2002). Topographic controls on erosion rates in tectonically active mountain ranges. Earth Planet. Sci. Lett. 201, 481-489. doi: 10.1016/S0012-821X(02)00725-2

Moody, J. A., Shakesby, R., Robichaud, P., Cannon, S., and Martin, D. A. (2013). Current research issues related to post-wildfire runoff and erosion processes. Earth Sci. Rev. 122, 10-37. doi: 10.1016/j.earscirev.2013.03.004

Munro, D. S., and Huang, L. (1997). Rainfall, evaporation and runoff responses to hillslope aspect in the Shenchong Basin. Catena 29, 131-144. doi: 10.1016/S0341-8162(96)00051-3

Nadeu, E., Berhe, A. A., De Vente, J., and Boix-Fayos, C. (2012). Erosion, deposition and replacement of soil organic carbon in Mediterranean catchments: a geomorphological, isotopic and land use change approach. Biogeosciences 9, 1099-1111. doi: 10.5194/bg-9-1099-2012

Naisse, C., Girardin, C., Lefevre, R., Pozzi, A., Maas, R., Stark, A., et al. (2015). Effect of physical weathering on the carbon sequestration potential of biochars and hydrochars in soil. Glob. Change Biol. Bioener. 7, 488-496. doi: $10.1111 /$ gcbb.12158

National Interagency Fire Center (2015). National Report of Wildland Fires and Acres Burned by State. Available online at: https://www.nifc.gov/fireInfo/ fireInfo_statistics.html (Accessed June 5, 2015).

Nearing, M. (1998). Why soil erosion models over-predict small soil losses and under-predict large soil losses. Catena 32, 15-22. doi: 10.1016/S0341-8162(97)00052-0

Neary, D. G., Klopatek, C. C., DeBano, L. F., and Ffolliott, P. F. (1999). Fire effects on belowground sustainability: a review and synthesis. For. Ecol. Manage. 122, 51-71. doi: 10.1016/S0378-1127(99)00032-8

Nguyen, B. T., and Lehmann, J. (2009). Black carbon decomposition under varying water regimes. Org. Geochem. 40, 846-853. doi: 10.1016/j.orggeochem.2009.05.004

Nguyen, B. T., Lehmann, J., Hockaday, W. C., Joseph, S., and Masiello, C. A. (2010). Temperature sensitivity of black carbon decomposition and oxidation. Environ. Sci. Technol. 44, 3324-3331. doi: 10.1021/es903016y

Nguyen, B. T., Lehmann, J., Kinyangi, J., Smernik, R., Riha, S. J., and Engelhard, M. H. (2009). Long-term black carbon dynamics in cultivated soil. Biogeochemistry 92, 163-176. doi: 10.1007/s10533-008-9248-x

Parsons, A. J., Brazier, R. E., Wainwright, J., and Powell, D. M. (2006). Scale relationships in hillslope runoff and erosion. Earth Surf. Process. Landforms 31, 1384-1393. doi: 10.1002/esp.1345

Parungo, F., Nagamoto, C., Zhou, M.-Y., Hansen, A. D., and Harris, J. (1994). Aeolian transport of aerosol black carbon from China to the ocean. Atmos. Environ. 28, 3251-3260. doi: 10.1016/1352-2310(94)00164-G

Pereira, P., Cerdà, A., Úbeda, X., Mataix-Solera, J., Arcenegui, V., and Zavala, L. (2015). Modelling the impacts of wildfire on ash thickness in a short-term period. Land Degr. Dev. 26, 180-192. doi: 10.1002/ldr.2195

Pierson, F. B., Moffet, C. A., Williams, C. J., Hardegree, S. P., and Clark, P. E. (2009). Prescribed-fire effects on rill and interrill runoff and erosion in a mountainous sagebrush landscape. Earth Surf. Process. Landforms 34, 193-203. doi: 10.1002/esp.1703

Pierson, F. B., Robichaud, P. R., Moffet, C. A., Spaeth, K. E., Hardegree, S. P., Clark, P. E., et al. (2008). Fire effects on rangeland hydrology and erosion in a steep sagebrush-dominated landscape. Hydrol. Process 22, 2916-2929. doi: 10.1002/hyp.6904

Pierson, F. B., Slaughter, C. W., and Cram, Z. K. (2001). Long-term stream discharge and suspended-sediment database, Reynolds Creek experimental Watershed, Idaho, United States. Water Resour. Res. 37, 2857-2861. doi: 10.1029/2001WR000420

Pierson, F. B., Williams, C. J., Hardegree, S. P., Clark, P. E., Kormos, P. R., and AlHamdan, O. Z. (2013). Hydrologic and erosion responses of sagebrush steppe following juniper encroachment, wildfire, and tree cutting. Rangeland Ecol. Manage. 66, 274-289. doi: 10.2111/REM-D-12-00104.1
Potter, M. (1908). Bacteria as agents in the oxidation of amorphous carbon. Proc. R. Soc. Lond. Ser. B Conf. Pap. Biol. Char. 80, 239-259. doi: 10.1098/rspb.1908.0023

Preston, C. M. (2009). Biogeochemistry: fire and it's black legacy. Nat. Geosci. 2:674 doi: 10.1038/ngeo642

Preston, C., and Schmidt, M. (2006). Black (pyrogenic) carbon in boreal forests: a synthesis of current knowledge and uncertainties. Biogeosci. Discuss. 3 , 211-271. doi: 10.5194/bgd-3-211-2006

Pyle, L. A., Hockaday, W. C., Boutton, T., Zygourakis, K., Kinney, T. J., and Masiello, C. A. (2015). Chemical and isotopic thresholds in charring: implications for the interpretation of charcoal mass and isotopic data. Environ. Sci. Technol. 49, 14057-14064. doi: 10.1021/acs.est.5b03087

Pyle, L. A., Magee, K. L., Gallagher, M. E., Hockaday, W. C., and Masiello, C. A. (2017). Short-term changes in physical and chemical properties of soil charcoal support enhanced landscape mobility. J. Geophys. Res. Biogeosci. 122, 3098-3107. doi: 10.1002/2017JG003938

Ravi, S., D’odorico, P., Zobeck, T. M., Over, T. M., and Collins, S. L. (2007). Feedbacks between fires and wind erosion in heterogeneous arid lands. J. Geophys. Res. Biogeosci. 112:G04007. doi: 10.1029/2007JG000474

Regnier, P., Friedlingstein, P., Ciais, P., Mackenzie, F. T., Gruber, N., Janssens, I. A., et al. (2013). Anthropogenic perturbation of the carbon fluxes from land to ocean. Nat. Geosci. 6, 597-607. doi: 10.1038/ngeo1830

Renard, K. G., Foster, G. R., Weesies, G., McCool, D., and Yoder, D. (1997) Predicting Soil Erosion by Water: A Guide to Conservation Planning with the Revised Universal Soil Loss Equation (RUSLE). Washington, DC: US Government Printing Office.

Riebe, C., Kirchner, J., Granger, D., and Finkel, R. (2001). Minimal climatic control on erosion rates in the Sierra Nevada, California. Geology 29, 447-450. doi: 10.1130/0091-7613(2001)029<0447:MCCOER >2.0.CO;2

Robichaud, P. R. (1997). Spatially-Varied Erosion Potential from Harvested Hillslopes after Prescribed Fire in the Interior Northwest. Ph.D. thesis, University of Idaho.

Rumpel, C., Ba, A., Darboux, F., Chaplot, V., and Planchon, O. (2009). Erosion budget and process selectivity of black carbon at meter scale. Geoderma 154, 131-137. doi: 10.1016/j.geoderma.2009.10.006

Rumpel, C., Chaplot, V., Planchon, O., Bernadou, J., Valentin, C., and Mariotti, A. (2006). Preferential erosion of black carbon on steep slopes with slash and burn agriculture. CATENA 65, 30-40. doi: 10.1016/j.catena.2005.09.005

Sander, M., and Pignatello, J. J. (2005). Characterization of charcoal sorption sites for aromatic compounds: insights drawn from single-solute and bi-solute competitive experiments. Environ. Sci. Technol. 39, 1606-1615. doi: 10.1021/es0491351

Santín, C., Doerr, S. H., Kane, E. S., Masiello, C. A., Ohlson, M., de la Rosa, M., et al. (2016). Towards a global assessment of pyrogenic carbon from vegetation fires. Glob. Chang. Biol. 22, 76-91. doi: 10.1111/gcb.12985

Santín, C., Doerr, S. H., Preston, C. M., and González-Rodríguez, G. (2015). Pyrogenic organic matter production from wildfires: a missing sink in the global carbon cycle. Glob. Chang. Biol. 21, 1621-1633. doi: 10.1111/gcb. 12800

Santos, F., Torn, M. S., and Bird, J. A. (2012). Biological degradation of pyrogenic organic matter in temperate forest soils. Soil Biol. Biochem. 15, 115-124. doi: $10.1016 /$ j.soilbio.2012.04.005

Schiettecatte, W., Gabriels, D., Cornelis, W., and Hofman, G. (2008). Enrichment of organic carbon in sediment transport by interrill and rill erosion processes. Soil Sci. Soc. Am. J. 72, 50-55. doi: 10.2136/sssaj2007.0201

Schmidt, M. W. I., and Noack, A. G. (2000). Black carbon in soils and sediments: analysis, distribution, implications, and current challenges. Glob. Biogeochem. Cycles 14, 777-793. doi: 10.1029/1999GB001208

Schmidt, M. W., Torn, M. S., Abiven, S., Dittmar, T., Guggenberger, G., Janssens, I. A., et al. (2011). Persistence of soil organic matter as an ecosystem property. Nature 478, 49-56. doi: 10.1038/nature 10386

Seiler, W. (1980). Estimates of gross and net fluxes of carbon between the biosphere and the atmosphere from biomass burning. Clim. Change 2, 207-247. doi: 10.1007/BF00137988

Shakesby, R. (2011). Post-wildfire soil erosion in the Mediterranean: review and future research directions. Earth Sci. Rev. 105, 71-100. doi: 10.1016/j.earscirev.2011.01.001 
Shakesby, R., Coelho, C., Ferreira, A., Terry, J., and Walsh, R. (1993). Wildfire impacts on soil-erosion and hydrology in wet Mediterranean forest, Portugal. Int. J. Wildland Fire 3, 95-110. doi: 10.1071/WF9930095

Shakesby, R., and Doerr, S. (2006). Wildfire as a hydrological and geomorphological agent. Earth Sci. Rev. 74, 269-307. doi: 10.1016/j.earscirev.2005.10.006

Sharpley, A. (1985). The selection erosion of plant nutrients in runoff. Soil Sci. Soc. Am. J. 49, 1527-1534. doi: 10.2136/sssaj1985.03615995004900060039x

Singh, N., Abiven, S., Torn, M. S., and Schmidt, M. (2012). Fire-derived organic carbon in soil turns over on a centennial scale. Biogeosciences 9, 2847-2857. doi: 10.5194/bg-9-2847-2012

Skjemstad, J. O. (1996). The chemistry and nature of protected carbon in soil. Aust. J. Soil Res. 34, 251-271. doi: 10.1071/SR9960251

Skjemstad, J., Taylor, J., and Smernik, R. (1999). Estimation of charcoal (char) in soils. Commun. Soil Sci. Plant Anal. 30, 2283-2298. doi: 10.1080/00103629909370372

Soucémarianadin, L. N., Quideau, S. A., Wasylishen, R. E., and Munson, A. D. (2015). Early-season fires in boreal black spruce forests produce pyrogenic carbon with low intrinsic recalcitrance. Ecology 96, 1575-1585. doi: 10.1890/14-1196.1

Stacy, E., Hart, S. C., Hunsaker, C. T., Johnson, D. W., and Berhe, A. A. (2015). Soil carbon and nitrogen erosion in forested catchments: implications for erosioninduced terrestrial carbon sequestration. Biogeosci. Discuss. 12, 2491-2532. doi: 10.5194/bgd-12-2491-2015

Stallard, R. F. (1998). Terrestrial sedimentation and the carbon cycle: coupling weathering and erosion to carbon burial. Glob. Biogeochem. Cycles 12, 231-257. doi: 10.1029/98GB00741

Torn, M., Trumbore, S., Chadwick, O., Vitousek, P., and Hendricks, D. (1997). Mineral control of soil organic carbon storage and turnover. Nature 389, 170-173. doi: $10.1038 / 38260$

Wang, Z., Govers, G., Steegen, A., Clymans, W., Van Den Putte, A., Langhans, C., et al. (2010). Catchment-scale carbon redistribution and delivery by water erosion in an intensively cultivated area. Geomorphology 124, 65-74. doi: 10.1016/j.geomorph.2010.08.010

Westerling, A. L., Hidalgo, H. G., Cayan, D. R., and Swetnam, T. W. (2006). Warming and earlier spring increase western US forest wildfire activity. Science 313, 940-943. doi: 10.1126/science.1128834

Whitman, T. L., Zhu, Z., and Lehmann, J. (2014). Carbon mineralizability determines interactive effects on mineralization of pyrogenic organic matter and soil organic carbon. Environ. Sci. Technol. 48, 13727-13734. doi: 10.1021/es503331y

Wiedemeier, D. B., Abiven, S., Hockaday, W. C., Keiluweit, M., Kleber, M., Masiello, C. A., et al. (2015). Aromaticity and degree of aromatic condensation of char. Org. Geochem. 78, 135-143. doi: 10.1016/j.orggeochem.2014. 10.002
Wiedemeier, D. B., Hilf, M. D., Smittenberg, R. H., Haberle, S. G., and Schmidt, M. W. (2013). Improved assessment of pyrogenic carbon quantity and quality in environmental samples by high-performance liquid chromatography. $J$. Chromatogr. A 1304, 246-250. doi: 10.1016/j.chroma.2013.06.012

Wischmeier, W. (1962). Storms and soil conservation. J. Soil Water Conserv. 17, 55-59.

Wischmeier, W. H., and Smith, D. D. (1965). "Predicting rainfall-erosion losses from cropland east of the Rocky Mountains-Guide for selection of practices for soil and water conservation," in Agriculture Handbook No. 282 (Washington, DC: United States Department of Agriculture), 1-47.

Wischmeier, W. H., and Smith, D. D. (1978). "Predicting rainfall erosion losses," in Agriculture Handbook No. 537 (Washington, DC: United States Department of Agriculture), 1-61.

Wondzell, S. M., and King, J. G. (2003). Postfire erosional processes in the Pacific Northwest and Rocky Mountain regions. For. Ecol. Manage. 178, 75-87. doi: 10.1016/S0378-1127(03)00054-9

Yao, J., Hockaday, W. C., Murray, D. B., and White, J. D. (2014). Changes in firederived soil black carbon storage in a subhumid woodland. J. Geophys. Res. Biogeosci. 119, 1807-1819. doi: 10.1002/2014JG002619

Zimmerman, A. (2010). Abiotic and microbial oxidation of laboratoryproduced black carbon (biochar). Environ. Sci. Technol. 44, 1295-1301. doi: 10.1021/es903140c

Zimmerman, A. R., and Gao, B. (2013). "The stability of biochar in the environment," in Biochar and Soil Biota, eds N. Ladygina and F. Rineau (Boca Raton, FL: CRC press), 1-40.

Zimmerman, A. R., Gao, B., and Ahn, M.-Y. (2011). Positive and negative carbon mineralization priming effects among a variety of biochar-amended soils. Soil Biol. Biochem. 43, 1169-1179. doi: 10.1016/j.soilbio.2011.02.005

Zimmermann, M., Bird, M. I., Wurster, C., Saiz, G., Goodrick, I., Barta, J., et al. (2012). Rapid degradation of pyrogenic carbon. Glob. Chang. Biol. 18, 3306-3316. doi: 10.1111/j.1365-2486.2012.02796.x

Ziolkowski, L., and Druffel, E. (2010). Aged black carbon identified in marine dissolved organic carbon. Geophys. Res. Lett. 37:L16601. doi: 10.1029/2010GL043963

Conflict of Interest Statement: The authors declare that the research was conducted in the absence of any commercial or financial relationships that could be construed as a potential conflict of interest.

Copyright (c) 2018 Abney and Berhe. This is an open-access article distributed under the terms of the Creative Commons Attribution License (CC BY). The use, distribution or reproduction in other forums is permitted, provided the original author(s) and the copyright owner are credited and that the original publication in this journal is cited, in accordance with accepted academic practice. No use, distribution or reproduction is permitted which does not comply with these terms. 